\title{
Current relevance of hypoxia in head and neck cancer
}

Review

\author{
Marius G. Bredell ${ }^{1}$, Jutta Ernst ${ }^{1}$, Ilhem El-Kochairi ${ }^{1}$, Yuliya Dahlem ${ }^{1}$, Kristian \\ Ikenberg ${ }^{2}$ and Desiree M. Schumann ${ }^{1}$ \\ ${ }^{1}$ Department of Cranio-, Maxillofacial and Oral Surgery, University Hospital Zürich, Zürich, Switzerland \\ 2 Department of Pathology, University Hospital of Zürich, Zürich, Switzerland \\ Correspondence to: Marius G. Bredell, email: marius.bredell@usz.ch
}

Keywords: hypoxia, head and neck cancer, oral cancer, biomarkers

Received: July 14, $2015 \quad$ Accepted: April 28, 2016

Published: May 21, 2016

\section{ABSTRACT}

Head and Neck cancer (HNC) is a complex mix of cancers and one of the more common cancers with a relatively poor prognosis. One of the factors that may assist us in predicting survival and allow us to adjust our treatment strategies is the presence of tumor hypoxia. In this overview we aim to evaluate the current evidence and potential clinical relevance of tumor hypoxia in head and neck cancer according to an extensive search of current literature.

An abundance of evidence and often contradictory evidence is found in the literature. Even the contradictory evidence and comparisons are difficult to judge as criteria and methodologies differ greatly, furthermore few prospective observational studies exist for verification of the pre-clinical studies. Despite these discrepancies there is clear evidence of associations between prognosis and poor tumor oxygenation biomarkers such as HIF-1a, GLUT-1 and lactate, though these associations are not exclusive. The use of genetic markers is expanding and will probably lead to significantly more and complex evidence. The lack of oxygenation in head and neck tumors is of paramount importance for the prediction of treatment outcomes and prognosis. Despite the wide array of conflicting evidence, the drive towards noninvasive prediction of tumor hypoxia should continue.

\section{INTRODUCTION}

Head and neck cancer (HNC) constitutes 5.1\% (> 633000 ) of all new cancers and relates to $4.8 \%$ of all cancer deaths annually worldwide with Head and Neck Squamous Cell Carcinomas (HNSCC) contributing by far the largest number [1]. Major risk factors are smoking (smokers are ten times more likely to develop HNSCC than non-smokers), alcohol abuse and HPV infection [2]. The main sites for HNSCC are the larynx, pharynx and oral cavity [1]. HNSCC is common only in its general anatomic localization as it is a diverse disease with regards to etiology, presentation, response to treatment and prognosis. Despite this diversity, there are some common features that may lead to local and regional recurrence and predict disease-specific survival. One of these features is the presence of hypoxia in the tumor [3].

Since hypoxic tumors show a poorer response to surgery and radiotherapy than non-hypoxic tumors, prior therapy knowledge on the presence and extent of the hypoxia is needed $[4,5]$. Currently, except for indwelling catheters, adequate information regarding the extent of the tumor hypoxia can only be gathered after tumor resection and histological processing. A wide array of tumor hypoxia biomarkers has been identified, however, to our knowledge no pre-excision predictive parameters are available. Except for the radio-oncology field where hypoxia predictive markers are now being implemented in some clinics, evidence is lacking regarding modifications that may be undertaken to optimize treatment [6-8].

The goal of this paper is to demonstrate the complexity, summarise and discuss the current literature evidence and potential clinical relevance of tumor hypoxia and its biomarkers in HNC. A PubMed and Medline search was performed using the keywords tumor hypoxia, pimonidazole, biomarkers, HIF-1alpha, CA-IX, Nitric oxide, smoking, anemia, VEGF, lactate, miRNA, head and neck cancer, and head and neck squamous cell carcinoma either alone or in combination. Articles were screened according to their level of clinical and scientific evidence 
as well as clinical relevance to the topic.

\section{WHAT IS TUMOR HYPOXIA?}

Tumor hypoxia can be defined as a low oxygen tension $\left(\mathrm{pO}_{2}\right)$ in the tumor compared to the surrounding tissue of $\mathrm{pO}_{2} \leq 2.5 \mathrm{mmHg}$, but is most commonly defined as a $\mathrm{pO}_{2} \leq 10 \mathrm{mmHg}$ [9]. A functional definition may be more appropriate in such an individualized and complex environment and therefore, at our current level of knowledge, tumor hypoxia starts when Hypoxiainducible Factors (HIF)-subunits become stabilized due to limited oxygen availability compared to oxygen demand. More than $50 \%$ of solid tumors display heterogenous hypoxic areas irrespective of their size and histological characteristics [10-12]. Oxygen content within tissues is dependent on a number of complex factors such as the physical presence of oxygen, the programming of tumor and stroma cells whether to utilize the available oxygen, vasculature, perfusion and diffusion distance that may be influenced by vascular density and edema, as well as systemic factors such as anemia or chronic obstructive lung disease.

\section{GENERAL CONDITIONS INFLUENCING TUMOR HYPOXIA}

\author{
Role of vasculature/microcirculation in tumor \\ hypoxia
}

The vasculature in tumors originate from host vessels and neovascularisation due to tumor angiogenesis factors [13]. If the incorporated vasculature is insufficient for the tumor mass, reduction in oxygen exchange will develop. This hypoxic state will stimulate reperfusion via neovascularisation in an attempt to restore the blood flow and improve the oxygen supply via a variety of metabolic pathways of which the HIF-1 alpha pathway is central $[14,15]$. This state of poor vascularity in terms of density, quality of blood flow, increased diffusion distance and permeability may also implicate poorer drug delivery and treatment response $[16,17]$.

The neovascularisation induced vessels are often tortuous and haphazard resulting in a sluggish perfusion, increased vessel permeability and distance from intact blood vessels [3, 18] (Figure 1). Therefore, a highly

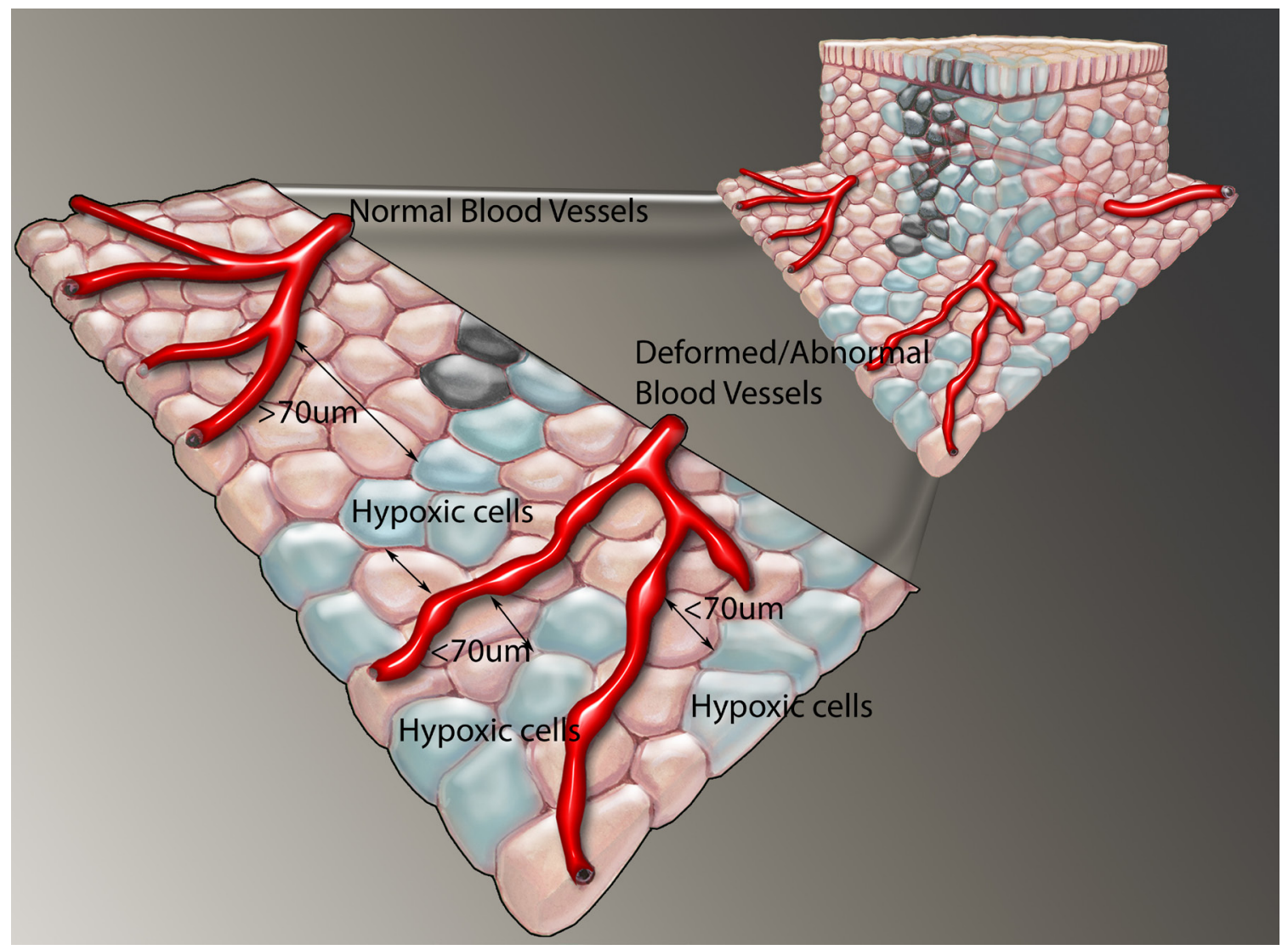

Figure 1: Tumor showing hypoxic cells beyond the oxygen diffusion limit of $70 \boldsymbol{\mu m}$ and close to newly formed tortuous, haphazard blood vessels that have sluggish perfusion. Functional venous drainage, preventing edema is also important, but not demonstrated here. 
vascularised tumor is not necessarily indicative of a highly oxygenated tumor [13]. This vascular-dependent relative hypoxic state does not necessarily lead to an anaerobic metabolic state of the tumor cells (Warburg effect).

Two subtypes of hypoxia have been described. Acute hypoxia is defined as a local disturbance in perfusion. The disturbance can be caused by the loss of microvascular blood flow or by strong variations in red blood cell fluxes which results in decreased microvascular oxygen supply to the tumor area due to the tortuous and aberrant vasculature and may be a transient phenomenon $[19,20]$. Upon revascularization with well-oxygenated blood, free oxygen radicals are released causing further tissue damage and even necrosis. When tumor growth is greater than neo-vascularisation, perivascular necrosis develops at a distance of $130-150 \mu \mathrm{m}$ from nutrient vessels and cells further away than $70 \mu \mathrm{m}$ from the vessels already show hypoxic tension indicating the oxygen diffusion limit (Figure 1). This phenomenon is called chronic or diffusion-limited hypoxia and can activate stressresponse genes and is typical of a re-vascularisation or re-oxygenation injury, explaining central necrosis, often found in fast growing tumors. This central necrosis is at least partially the cumulative end result of both acute and chronic hypoxia in the tumor microenvironment [21]. Especially in initial stages, cancer cells may also need other growth factors, and they will be selected by necrosis until they gain a mutation that renders them growth factor independent. Generating a universal definition of hypoxia may thus be difficult and probably needs to sub-defined depending on the particular measurement assay which may be physical or a genetically or local environment dictated metabolic measurement. Important also is to consider noninherent tumor factors, like anemia, smoking, decreased lung function or post radiation related poor perfusion in HNC patients that may influence tumor hypoxia. Decreased blood flow has a negative effect on the oxygen delivery to a tumor area and this is often termed hypoxia, but strictly defined, the term ischemia should be used for this phenomenon. Hypoxemia is defined as less oxygen in the blood due to decreased hemoglobin-oxygen saturation.

\section{Anemia and tumor hypoxia}

Anemia plays a role in tumor hypoxia [13]; it is defined as a hemoglobin $(\mathrm{Hb})$ level less than $12.0 \mathrm{~g} /$ $\mathrm{dl}$ in females and less than $13.8 \mathrm{~g} / \mathrm{dl}$ in males, and has long been known as a prognostic factor in HNC [3]. Postoperative acute anemia $(\mathrm{Hb}<12 \mathrm{~g} / \mathrm{dl})$ has been described as an independent prognostic factor for local recurrence-free survival [5, 22, 23]. Nordsmark et al. [24] and Nordsmark [25] found a correlation between median $\mathrm{pO}_{2}$ levels (9 $\mathrm{mmHg}$; range 0-62 $\mathrm{mmHg}$ ) and $\mathrm{Hb}$ levels but when they subcategorized into $\mathrm{pO}_{2}<2.5 \mathrm{mmHg}$ and $\mathrm{pO}_{2}<5 \mathrm{mmHg}$, they found no correlation between $\mathrm{pO} 2{ }_{2}$ and $\mathrm{Hb}$.

Pre-operative anemia plays a significant role in overall survival [23]. Low Hb levels may impair survival by impairing tissue and possibly tumor oxygenation causing hypoxia and thereby reducing the effectiveness of chemotherapy and radiotherapy [26, 27]. Compounding the complexity of the matter is evidence that blood transfusion may lead to a worse prognosis [28]. Bhide et al. [29] and Hoff et al. [30] found that blood transfusion before and during radiotherapy in HNC patients had no effect on survival and may in fact be deleterious. This paradox may be explained by the leakage of endothelial growth factors from the aging red blood cells that may encourage tumor growth and have a deleterious effect on immune regulation. This evidence should encourage us to move away from the common notion of transfusing patients with an $\mathrm{Hb}<10 \mathrm{~g} / \mathrm{dl}$ or a hematocrit (Hct) $<30 \%$. Vaupel et al [31] found that an $\mathrm{Hb}$ level between 12 and $14 \mathrm{~g} / \mathrm{dl}$ was optimal for tumor oxygenation even though no correlation has been found between $\mathrm{Hb}$ level and $\mathrm{pO}_{2}$ $[32,33]$.

Erythropoietin (EPO) is a glycoprotein that regulates erythrocyte production by stimulating growth, preventing apoptosis and inducing differentiation of red blood cell precursors. Increasing the $\mathrm{Hb}$ levels with EPO has led to contradictory results. Henke et al. [34] showed a decrease in recurrence in pelvic malignancies in patients administered erythropoietin alfa and iron compared to patients who received iron only. It was later shown that EPO treatment during radiotherapy may have a detrimental effect on loco-regional progression-free survival and overall survival in HNC patients despite an increased $\mathrm{Hb}$ [35]. This negative effect of EPO could be due to the fact that the $\mathrm{Hb}$ levels were increased to around $14.8 \mathrm{~g} / \mathrm{dl}$ which falls outside the beneficial range $(12 \mathrm{~g} / \mathrm{dl}$ to $14 \mathrm{~g} / \mathrm{dl}$ ) suggested by Vaupel et al [31]. This argument is controversial because in the experiments performed by Glaser et al [36], two groups had a starting $\mathrm{Hb}$ level > $14.5 \mathrm{~g} / \mathrm{dl}$ and these patients had a good overall response to neo-adjuvant chemotherapy. Neither Henke et al. [35] nor Glaser et al. [36] investigated the effects of EPO administration on tumor hypoxia. In vivo, EPO appears to have no effect on tumor growth or radiotherapy efficacy $[37,38]$. Furthermore, no correlation has been found between $\mathrm{Hb}$ and tumor hypoxia markers such as HIF1alpha, HIF-2alpha, and Carbonic Anhydrase-IX (CA-IX) $[39,40]$, however in a cervical cancer cohort anemia did correlate with HIF-1alpha expression [27].

Total $\mathrm{Hb}$ levels cannot be used to indirectly determine oxygen delivery to tissue as it does not take into account blood flow, $\mathrm{Hb}$ saturation, oxygen- $\mathrm{Hb}$ dissociation, or the quality of the $\mathrm{Hb}$ [41].

Although no overwhelming evidence, anemia has been shown to interrelate anemia and tumor hypoxia, anemia remains an important factor in patient survival. There is, however, evidence that implicates carboxyhemoglobin in tumor hypoxia. 


\section{Smoking and tumor hypoxia}

Smoking is one of the main risk factors for HNSCC and the main source of carbon monoxide (CO). Patients who continue smoking during radiation have a worse prognosis than non-smokers [42, 43]. Carboxyhemoglobin is defined as $\mathrm{Hb}$-bound $\mathrm{CO}$ [44]. Hb has an approximately 200-280 fold higher affinity for CO than for oxygen, therefore low amounts of $\mathrm{CO}$ will impact on the oxygenhemoglobin dissociation curve by shifting it left, resulting in diminished tumor blood perfusion as well as the amount of oxygen bound to $\mathrm{Hb}$ [44]. Increased $\mathrm{HbCO}$ in $\mathrm{HNC}$ patients who smoke, results in a decreased oxygen unloading capacity [41]. This means that most of the oxygen that enters a tumor subsequently leaves the tumor in venous blood outflow. A rise of $\mathrm{HbCo}$ to $12 \%$ (compared to the average of $4.6 \%$ in smokers) results in a $25 \%$ reduction in oxygen available to the tumor [41]. CO causes a $50 \%$ reduction in blood flow to tumors and a 50 $\%$ increase in tumor hypoxia in mice [45].

Cigarette smoke also contains nicotine which impairs wound healing by vasoconstriction thus decreasing blood flow to the wound [46]. Nicotine and its derivatives play a role in tumor progression and metastasis by increasing oxidative stress and activating NF-kappaB and other proliferation signaling pathways [47]. Nicotine promotes proliferation of nasopharyngeal carcinoma cells by inducing HIF-1alpha and vascular endothelial growth factor (VEGF) and inhibiting pigment epithelium-derived factor (PEDF), a known anti-angiogenic, anti-tumorigenic protein [48].

\section{Alcohol and tumor hypoxia}

Alcohol and more so, alcohol and smoking combined, are major risk factors for HNSCC (Figure 2) as alcohol may act as a solvent for cigarette smoke. Although no direct correlations have been made between alcohol and tumor hypoxia, alcohol increases HIF-1alpha via oxidative stress in a rat model for alcoholic liver disease [49]. Alcohol is metabolized to acetaldehyde, a known carcinogen, by alcohol dehydrogenase (ADH) situated in the liver, gastric mucosa, oesophageal mucosa and oral mucosa [50]. Most of the harmful effects of alcohol are mediated via acetaldehyde through DNA damage, but alcohol can increase mucosal permeability and cause changes in mucosal morphology [50]. The relationship between alcohol consumption and tumor hypoxia in HNC has not been investigated thus far. However, baboons fed alcohol chronically showed decreased oxygen consumption in the liver accompanied by increased acetaldehyde concentrations and impaired mitochondrial function [51]. It is therefore possible that alcohol also plays a role in tumor hypoxia in HNSCC. Not all HNSCC patients drink alcohol and/or smoke tobacco which brings our focus to the human papillomavirus.

\section{Human Papillomavirus (HPV) and tumor hypoxia}

HPV causes up to $70 \%$ of oropharyngeal cancers but less oral cancers. Contradicting results exist pertaining to the effect of HPV on HIF-1alpha. HPV-16 induces HIF-1alpha expression in vitro and ex vivo in head and

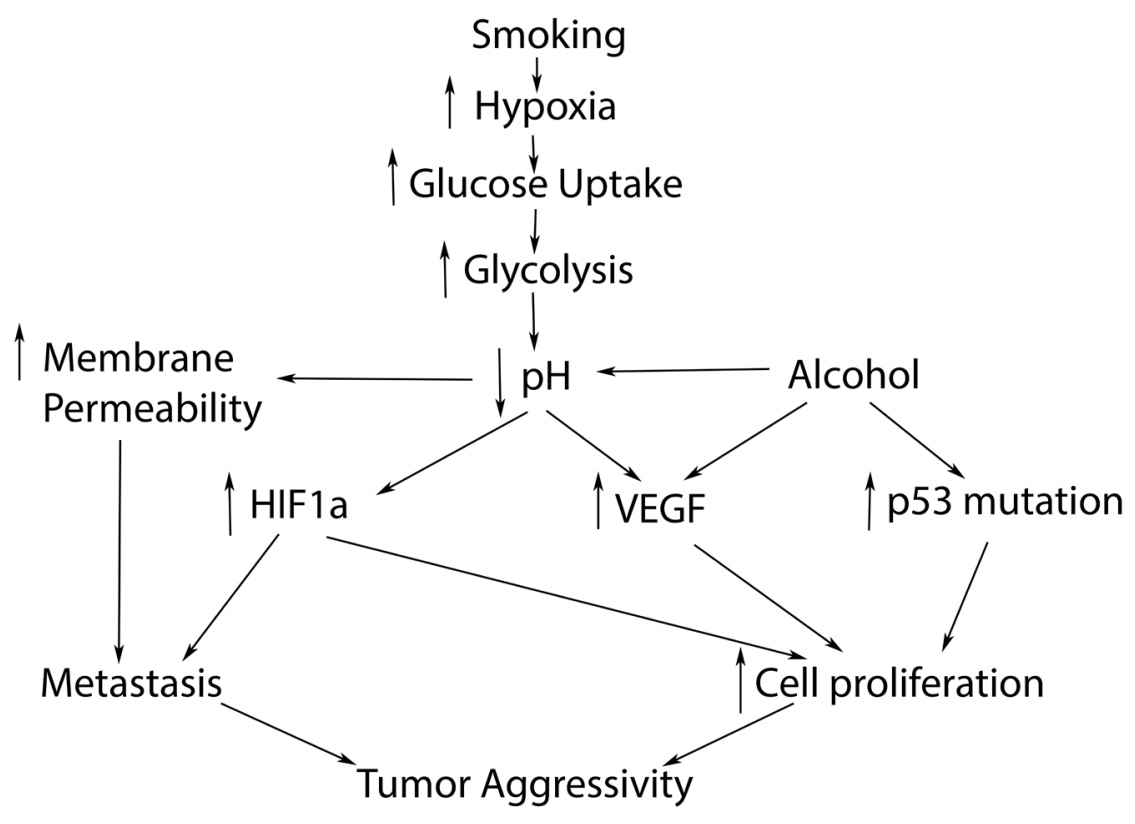

Figure 2: Hypoxic pathway possibly relates to smoking, leading to increased tumor aggressivity and poorer prognosis in HNC. 
neck tumor specimens [52-54]. Hong et al. [55] however, found no relationship between HPV-status and HIF-1alpha expression in patients with oropharyngeal cancer but patients with the worst prognosis tended to be those who were HPV-negative and HIF-1alpha positive.

HPV-positive tumors grow faster and show aggressive regional metastasis, yet the patients have a better prognosis and a better response to radio- and chemotherapy [56]. Comparatively, tumor hypoxia has also been linked to increased metastasis, but has a worse prognosis and a worse response to radio- and chemotherapy. Rodolico et al. [54] concluded that the increase in HIF-1alpha in HPV-positive tumors was oxygen-independent since the HIF-1alpha immune reactivity also occurred close to blood vessels, however Janssen et al. [57] also found that this immunoreactivity did not correlate with the pimonidazole staining. Trinkaus et al. [58] could not find an association between p16positive patients with locally advanced head and neck tumors and hypoxic imaging using (18F)-misonidazole positron emission tomography, equally Mortensen et al. [59] could not demonstrate this by use of FAZAPET in the DAHANCA trial. One would expect a less pronounced hypoxia association as HPV-positive patients with oropharyngeal cancer mostly have a more favorable prognosis, however the role of HPV in tumor hypoxia still has to be fully explored. Comprehensive gene profiling of HNSCC has been performed, highlighting the different pathways of HPV and non HPV induced HNSCC, but not yet covering all hypoxia pathways [60].Comprehensive discussion of HPV and its relation to HNSCC is not within the scope of this paper.

HPV causes HNSCC in a different way with, nonmutated p53 and producing E6 and E7 oncogenes with its own unique way to manipulate the immunological system. Clearly immunity is becoming a focal point of cancer research.

\section{Immune system and tumor hypoxia:}

Inflammation appears to play a central role in the development of cancer and as far back as 1863, Virchow postulated that a process of chronic irritation or irritants may lead to injury and an inflammatory process that will enhance cell proliferation and development of cancer, including oral cancer $[61,62]$. Cigarette smoke also affects the immune system by impairing immunity in the oral cavity and promoting gingival and periodontal disease and oral cancer [63]. Cigarette smoke contains bacterial lipopolysaccharides, reactive oxygen species and other reactive compounds that induce chronic inflammation in the oral mucosa and modify host responses to exogenous antigens [63]. Viral infections and especially HPV in HNSCC may play a role in immunosuppression by infecting pluripotent stem cells, resulting in oncogenic changes that are replicated in the background of a poorly responsive immune system $[10,62,64]$. The expressions of the viral oncogenes E6 and E7 are important in the process of changing stem cells because they lead to the inactivation of one of the immune defense mechanisms, the tumor suppressor genes $\mathrm{p} 53$ and pRb [65]. A biological explanation for the improved prognosis of HPV-positive versus HPV-negative cancer patients has not been established. Bose et al. [10] hypothesized that p53 and $\mathrm{pRb}$ remain intact in HPV-positive cases whereas they are mutated in HPV-negative cases.

Multiple pathways for the initiation and later association and reactive changes of inflammation and tumor development have been described. Loss of cellular senescence and development of cancer stem cells may be propagated by stress factors like inflammation and hypoxia [66]. Chronic inflammation associated with poor oral hygiene and Lichen Planus (an autoimmune disease) and oral cancer has been shown in more than $1 \%$ of afflicted patients [62]. In early premalignant lesions, inflammation-induced neovascularisation has been observed in the stromal component of verrucous hyperplasia and hyperkeratosis [67]. The composition of cytokine/chemokines, liberated from monocytes at a site of inflammation and which are important in the development of a chronic state of disease, can broadly be divided into pro-inflammatory and anti-inflammatory cytokines. One of these cytokines is tumor necrosis factor- $\alpha$ (TNF- $\alpha$ ), a pro-inflammatory cytokine that has both a positive and negative effect on inflammation and has a controlling effect on pro-inflammatory cell populations. Interleukins 1 and 6 are associated with tumor metastasis and interleukins 8 and 12 have been associated with inflammation and cancer $[61,62]$.

The role of inflammation, hypoxia, lactate, glucose metabolism and angiogenesis in oncogenesis is highlighted by various associations like CXCL12 that may play a role in the immune response by activating CD8 and T cells in established HNSCC $[62,68]$. CXCR4 and CXCL12, both also described as HIF targets, are highly expressed in HNSCC and correlate with poor prognostic outcome due to increased metastasis and increased resistance to therapy [69]. Glucose and its possible role in tumor hypoxia, along with diabetes is described later in this manuscript.

In a study by Dumitru et al. [70] an association between AHNAK/Desmoyokin, a giant protein associated with poorer immune defense and an increased migration inhibitory factor (MIF, also a HIF target), and increased level of neutrophil tumor infiltration was established in laryngeal cancer patients with poor prognosis. Factors released by neutrophils enhance tumor migration in a feedback manner [70]. The role of the inflammatory process and its controlling proteins and prescribing gene pool is intricate and new discoveries slowly enhance our understanding.

Up to now we have described the interplay between the tumor environment and tumor hypoxia. Pimonidazole, 
an exogenous biomarker for tumor hypoxia, has thus far been the gold standard. Endogenous biomarkers such as LDH-5, HIF-1 $\alpha$, CA-IX, GLUT-1 and MCT4 may show some clinical relevance [8, 57, 71-73].

\section{ENDOGENOUS BIOMARKERS IN TUMOR HYPOXIA}

It is important to recognize that most biopsy specimens are adequate for diagnosis of malignancy, but may not be a representative metabolic sample of the tumor. This is because: 1. Biopsy specimens are taken from variable, mostly peripheral parts of the tumor that may represent different states of perfusion [10]; 2 . Tumors often show heterogenous metabolic activity and large tumors display areas of acute and chronic hypoxia that may not be represented by a single or even multiple biopsies [25]; 3. Tumor hypoxia is a dynamic process and tumors may display signs of hypoxia earlier or later in their development; and 4. Hypoxia is not a sizedependent factor and shows a poor relationship with other clinicopathological factors like differentiation and lymph node metastasis. Despite the above, a significant relationship to prognosis exists, demonstrating poor sensitivity, specificity and a poor understanding and interrelationship of our current prognostic predictive methods $[3,15]$.

Janssen et al. [3] raised interesting questions regarding the endogenous markers for hypoxia - i.e. is the marker only dependent on hypoxia for its expression or do other factors play a modulating role? Is the marker expressed (under hypoxia) in all tumor types? Is the marker expressed under acute and chronic hypoxia i.e. what is the time scale for upregulation after hypoxia induction? With these questions in mind, we discuss the more common biomarkers used for tumor hypoxia.

\section{HIF and tumor hypoxia}

HIF form a family of heterodimeric transcription factors that are upregulated in response to hypoxia and regulate hypoxia-driven changes in tumor cells. HIF1alpha is a member of this family and is often used as a marker for tumor hypoxia. The understanding thus far has been that in normoxic conditions, HIF-1alpha subunits are degraded whereas in hypoxia, the degradation is inhibited when the enzymes that modify HIF become inactive. HIF-1alpha then binds to hypoxia response elements and regulates changes in expression of VEGF, CA-IX, glucose transporter (GLUT-1), EPO, plasminogen activator inhibitor-1 (PAI-1) and others (Figure 3). In recent years it has been shown that HIF-1alpha expression is not only regulated by hypoxia but by nitric oxide [74-76], reactive oxygen species $[76,77]$, cytokines and growth factors such as TGF-beta [78, 79] and insulin [80], factors not necessarily associated with tumor hypoxia. HIF-1alpha is activated at physiological $\mathrm{pO}_{2}$ in a mitogen activated protein kinase (MAPK)-dependent manner and is needed

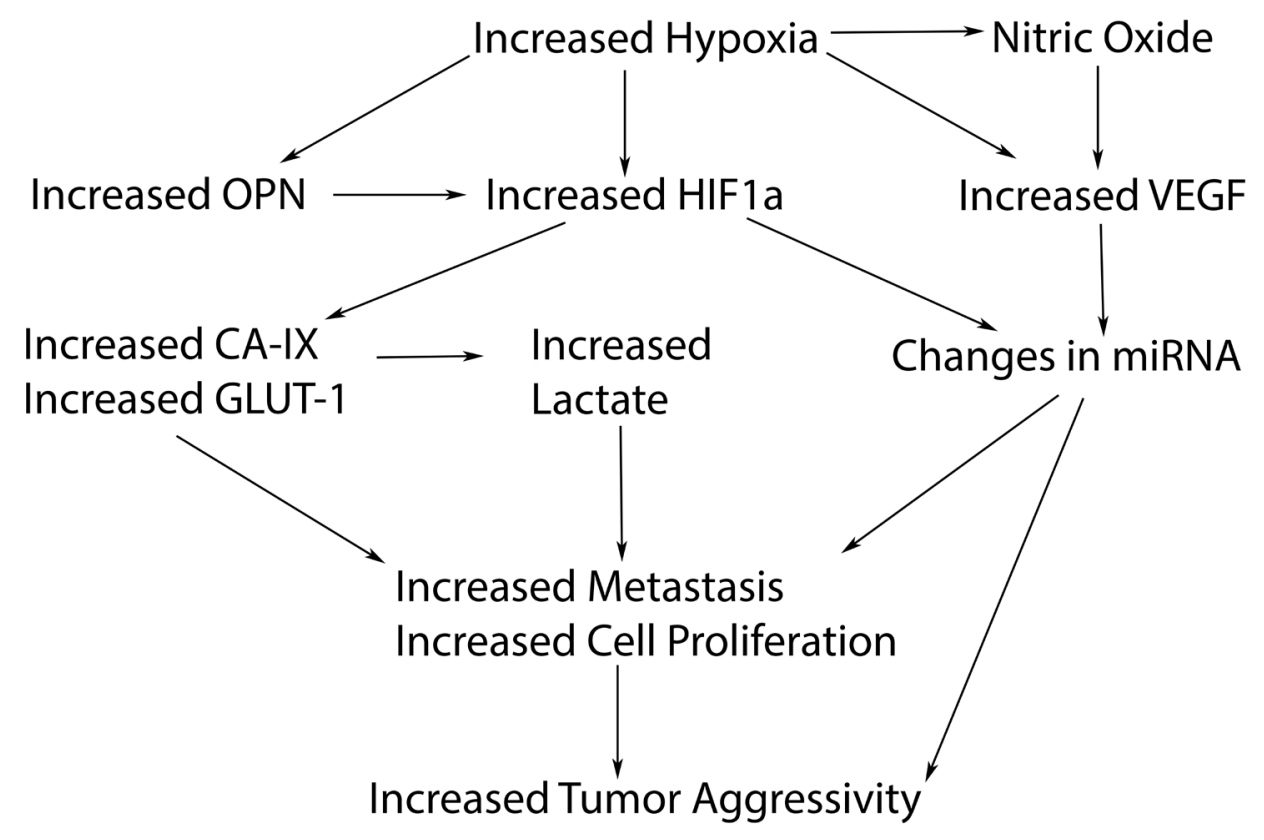

Figure 3: Hypoxic related biomarkers that may play a role in the hypoxic pathway leading to increased tumor aggressivity. 
for proliferation various cancer cell lines and in normal human keratinocyte cells [81]. Janssen et al. [57] found no correlation between pimonidazole and HIF-1alpha staining and concluded that HIF-1alpha is not a suitable marker for chronic hypoxia. It would appear that HIF-1alpha is only transiently induced and then undergoes (partial) feedback inhibition [82]. Pimonidazole staining increased with distance from the blood vessels which corroborated the findings of Wijffels et al. [83]. Furthermore, Joshi et al. [84] recently found that hypoxia alone is not sufficient to stabilize HIF-1alpha and that HIF-1alpha can be degraded during hypoxia by the $26 \mathrm{~S}$ proteasome via the E3 ligase MDM2 [84].

Diabetes is recognized as a risk factor for oral cancer [85]. In an epidemiological study in Hungary, 24.3 $\%$ of the patients who had malignant oral lesions also had impaired glucose metabolism [86]. A higher percentage of type 2 diabetic patients, who are characterized by increased circulating insulin due to insulin resistance, had malignant lesions compared to type 1 diabetic patients. Cholesterol and insulin (both of which are elevated in Type 2 diabetes) increase HIF-1alpha. Although the effects of HIF-1alpha, along with VEGF are not unique to hypoxia, they are of significant therapeutic interest.

\section{VASCULAR ENDOTHELIAL GROWTH FACTOR (VEGF) AND TUMOR HYPOXIA}

VEGF is a hypoxia-responsive gene and is a key player in the development of tumor vascularisation [87]. Increased VEGF production by tumor cells is associated with poor prognosis, nodal metastasis, clinical stage and low survival in HNSCC [88]. It is upregulated in decreasing concentrations of oxygen in vitro and in vivo [89-91] in HNSCC via Jun N terminal kinase (JNK-1) and p38 kinase which are stress activated protein kinases [92]. To further complicate matters, VEGF is also regulated by many other factors in normoxic conditions [93].

Kennedy and Frank [94] investigated human retinal epithelial cells and confirmed the findings of Katavetin et al. [95] who showed that high glucose levels diminished the effect of hypoxia on VEGF. Low glucose and hypoxia (i.e. low $\mathrm{pO}_{2}$ ) resulted in a significant increase in VEGF levels and the authors concluded that the cells used VEGF and angiogenesis as a compensatory mechanism when both fuel sources (oxygen and glucose) were depleted. As clearly shown in Figure 4, tumor cells need a high concentration of glucose, a fact exploited in FDG (FFluordesoxyglucose) PET scans.

Tumors will not grow larger than $1-2 \mathrm{~mm}^{3}$ if neovascularisation, with the formation of an intra-tumor capillary network, does not take place. Neovascularisation

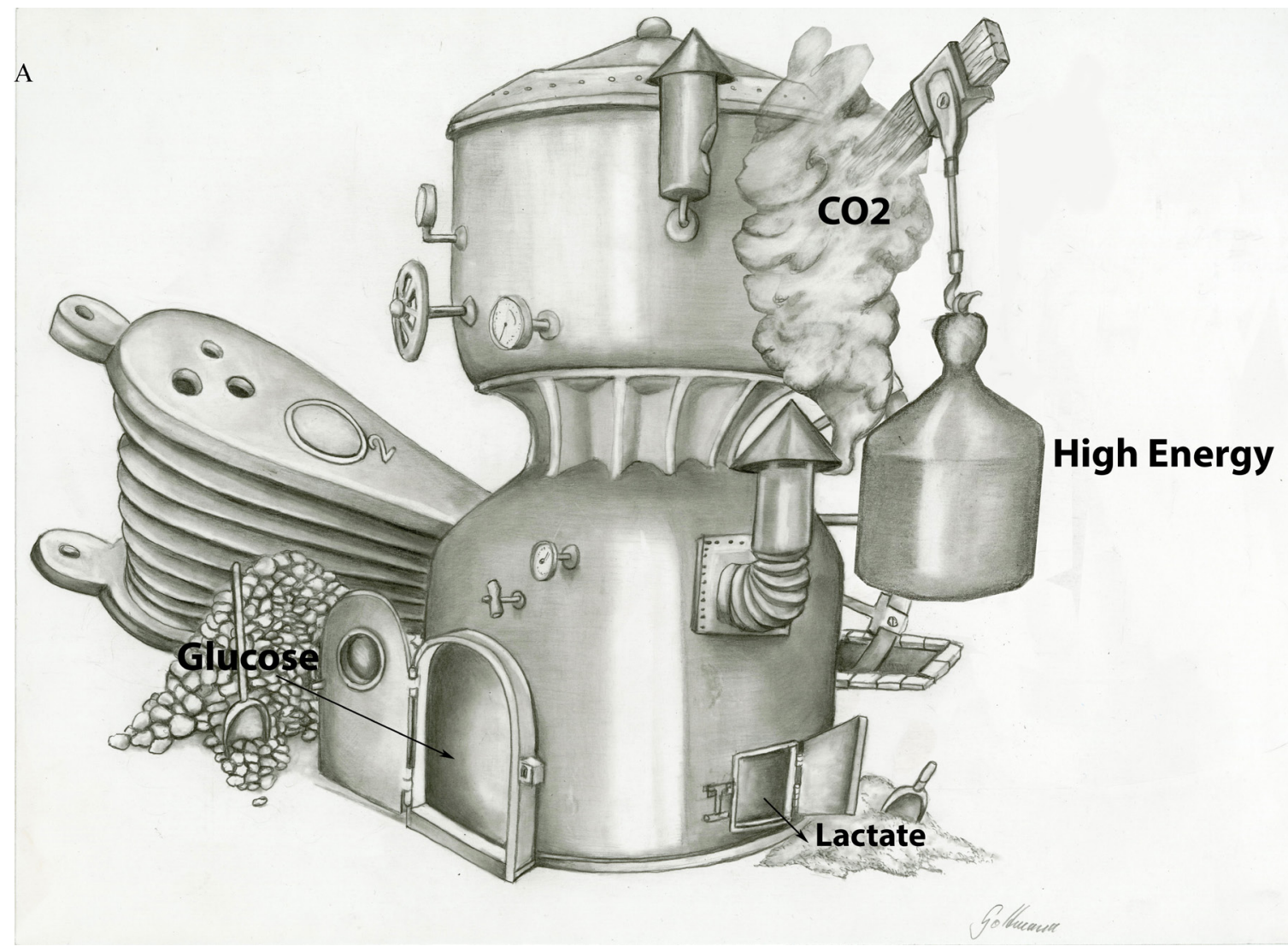




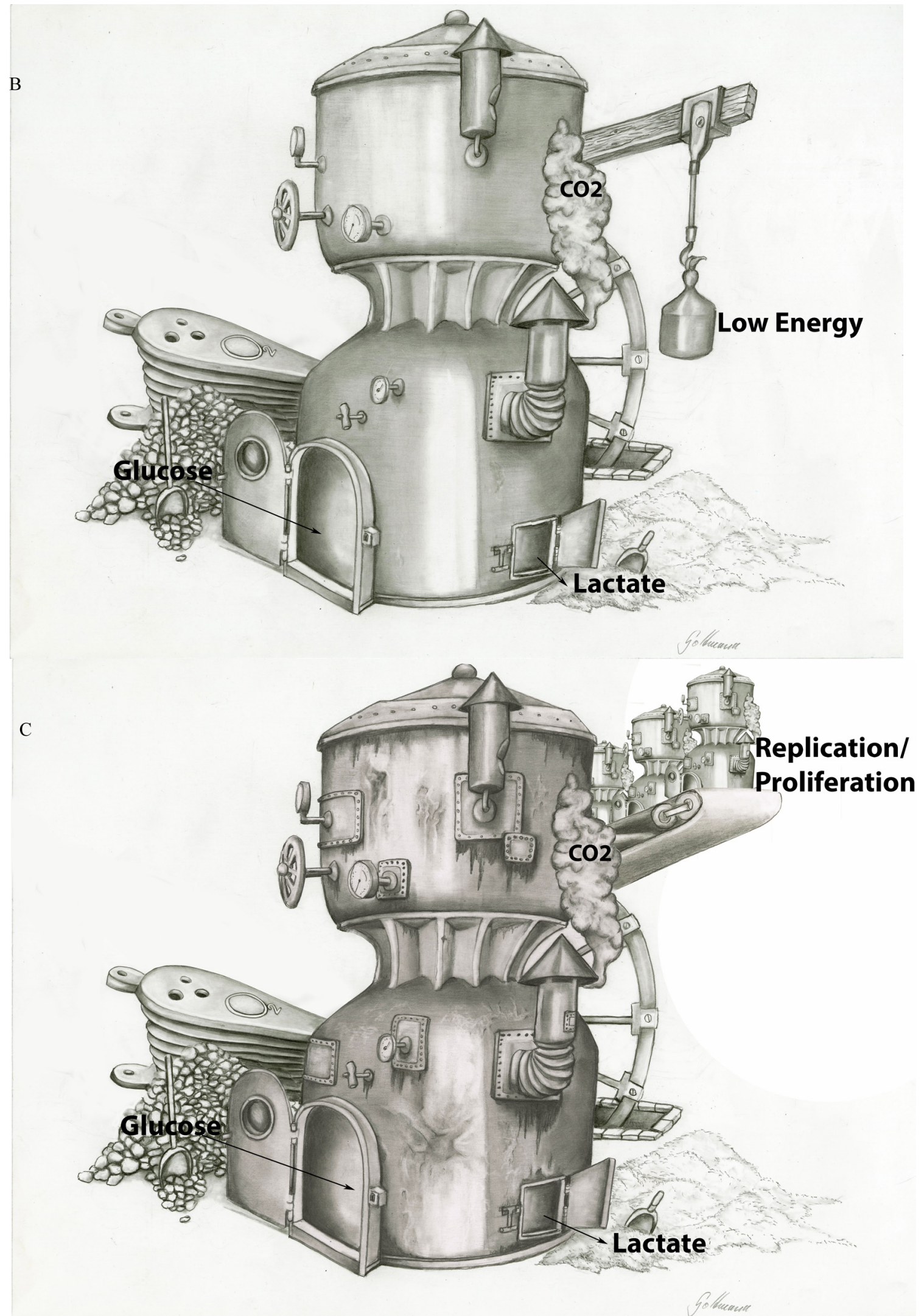

Figure 4: Oxidative phosphorylation in the presence of a) high levels of or b) low levels of oxygen, where glucose is metabolized to $\mathrm{H}_{2} \mathrm{O}$ and $\mathrm{CO}_{2}$ with the production of a) high ATP or b) low ATP in a normal cell. c) Proliferating or tumor cells produce low levels of ATP and convert glucose into lactate in the presence of oxygen. This is called aerobic glycolysis or the Warburg effect. It is postulated that tumor cells use the energy for proliferation and replication. 
seems mainly to be induced by VEGF but recently nitric oxide (NO) has also been implicated in this process [89, 96]. Hypoxic head and neck tumors have a high glucose uptake and the pimonidazole staining for hypoxia shows that the cells are far from blood vessels [3]. Shi et al. [97] implicated VEGF in cell proliferation. It is therefore possible that the induction of VEGF by chronic hypoxia (which occurs far from the blood vessels and is associated with a high glucose uptake) is for cell proliferation and not for angiogenesis whereas acute hypoxia (which is found closer to stunted and/or blind blood vessels) induces VEGF for angiogenesis.

VEGF's role in tumor oxygenation via the vascularisation mechanism remains undisputed and needs to be considered in all assessments of tumor hypoxia.

\section{Glucose transporter 1 (GLUT-1) and tumor hypoxia}

Cells primarily use glucose as an energy source which is converted to $\mathrm{H}_{2} \mathrm{O}$ and $\mathrm{CO}_{2}$ to produce ATP in the presence of oxygen (oxidative phosphorylation). In the absence of oxygen, glucose is converted to lactate (anaerobic glycolysis, Figure 4). Otto Warburg and his co-workers in 1920 demonstrated that compared to normal cells, tumor cells have a significant predilection for glucose metabolism under aerobic conditions, coined the Warburg effect $[98,99]$. In his focus on glycolysis, Warburg demonstrated a reversed Pasteur effect by the inhibition of oxygen fermentation, implicating the glycolytic production of lactate even in the presence of sufficient oxygen, thus bypassing the entry of pyruvate into the citric acid cycle. The protons diffuse out of the cell into the extracellular environment to maintain intracellular homeostasis $[98,99]$.

Increased HIF-1alpha is associated with increased glucose consumption in a renal cell carcinoma cell line [100]. More glucose transporters are needed for more glucose uptake, so increased GLUT1, a glucose transporter, correlates with poor outcome for HNSCC patients, since it decreases apoptosis and therefore favors tumor growth [101, 102]. Grimm et al. [101] found that patients with increased GLUT1 and transketolase-like protein 1 (TKTL1) had a worse prognosis compared to patients with low GLUT1 and low TKTL1 levels. Mayer et al. [103] has questioned the antibody used for TKTL1 detection and concluded that TKTL1 does not regulate glucose metabolism in malignant cells. Parallel to lactate production, tumor tissue is acidified, has increased invasiveness and eventually leads to metastasis [104]. The increase in lactate caused by the increased glycolysis could be used as a biomarker in measuring tumor hypoxia.

\section{Lactate and tumor hypoxia}

It seems that any proliferating cell can use aerobic glycolysis [98] and that leukemia cells and lung cancer cells that are in direct contact with the bloodstream are highly glycolytic. Peppicelli et al. [105] hypothesized that increased hypoxia leads to increased glycolysis resulting in increased lactate and therefore increased acidosis which in turn compromises the surrounding cells and results in increased metastasis. This hypothesis was based on the investigations by Brizel et al. [106] and Ziebart et al. [107]. Ziebart et al. [107] took biopsies from 29 HNSCC patients with stage T3 or T4 tumors and from 9 control patients. They showed that lactate was increased and glucose was decreased in tumors compared to normal tissue. Walenta et al. [104] found that high tumor lactate levels, as measured by bioluminescence imaging, correlated to increased incidence of metastasis, tumor recurrence and a decreased overall survival. They found a positive correlation in the distribution patterns of ATP, glucose and lactate which is surprising considering that aerobic glycolysis is known to be an inefficient form of ATP production. Furthermore, lactate was not correlated to tumor hypoxia. Mariappan et al. [108] found a correlation between serum lactate levels and brain tumor grade. Unfortunately, no systemic condition of the patient was taken into account, especially since diabetic patients and chronic alcoholism have a higher basal serum lactate level than non-diabetic patients $[109,110]$. No correlation was found between lactate levels and tumor staging $[106,107$, 111]. Lactate transporter monocarboxylate transporter 4 (MCT-4) has to be induced by hypoxia and MCT-1 is needed to transport lactate in surrounding tumor cells. MCT-1 expressing cells show expression of KI-67 as well, indicating a higher replication.[112] HPV-positive cell lines appear to metabolise lactate more efficiently than HPV-negative cell lines [113]. Thus far, tumor lactate has been correlated with and seen as a reliable metabolic predictor for poorer prognosis and metastasis but the relationship between tumor hypoxia and lactate is still unclear [114].

\section{Lactate Dehydrogenase (LDH) and tumor hypoxia}

Lactate dehydrogenase catalyzes the reversible conversion of pyruvate to lactate. Lactate dehydrogenases are hetero or homo tetramers encoded by LDHA and LDHB genes. There are five isoenzymes: LDH1, LDH2, LDH3, LDH4 and LDH5. LDH5 expression independently correlates with poor prognosis and metastasis in HNSCC and is not expressed in normal head and neck mucosa [115]. Oropharyngeal tumors have higher LDH5 expression than other head and neck tumors. The serum LDH level in HNSCC patients is an independent prognostic factor and Hsieh et al. [116] and 
Yao et al. [117] found that serum LDH above the upper limit of normal correlates with poor survival. LDH activity in saliva has also been correlated with periodontal disease [118]. LDH expression is significantly increased $(88 \%)$ in saliva from oral squamous cell cancer patients compared to age and sex-matched controls, independent of smoking, alcohol consumption and other diseases [119]. On the other hand an inverse correlation between tumor grade and LDH activity has been shown, furthermore HNSCC tumor cell lines xenografted into mice showed a correlation between LDH and pimonidazole staining [120, 121]. Although increased serum LDH is mainly correlated with the incidence of cancer, its expression increases drastically during infection [122]. A link between both serum and tumor LDH and tumor hypoxia and prognosis is well established and should be included in future investigations.

\section{CA-IX (Carbonic Anhydrase IX) and tumor hypoxia}

CA-IX comes from a family of zinc metalloenzymes that catalyze the reversible hydration of carbon dioxide. It is a transmembrane protein involved in various biological processes such as acid-base balance, the formation of saliva, cerebrospinal fluid and gastric acid and may be involved in cell proliferation. CA-IX is a prognostic marker for a number of malignancies [123]. In cervical cancer [124] and in HNSCC patients [25] there is no correlation between CA-IX staining and $\mathrm{pO} 2$ values. This is not supported by all research as Beasley et al. [125] confirmed the hypoxia dependent induction of CA-IX in three HNSCC cell lines.

A meta-analysis including 16 studies and 1470 patients showed that CA-IX is correlated with poor survival independent of tumor hypoxia [126]. The metaanalysis did not take into consideration the different locations of the HNSCCs, only tumor size, tumor grade and nodal status. Brockton et al. [127] analysed 91 biopsy samples from HNSCC patients who had radio- and chemotherapy and found that CA-IX was not correlated to smoking status, gender, age, tumor site, tumor stage, performance status or response to therapy . They did, however, find a correlation between high stromal CA-IX levels and HPV p16-negative status and poor survival. In a cohort of 61 HNSCC patients with mainly HPV p16negative tumors, there was no correlation between CAIX and gender, age, tumor site, tumor stage, performance status or response to therapy but a correlation between CA-IX and smoking status and between high stromal CAIX and poor survival existed [128]. So, there seems to be prognostic relevance with a high stromal expression of CA-IX, however, our assessment may not be reliable or sensitive enough to verify its clinical relevance in tumor hypoxia.

\section{Osteopontin and tumor hypoxia}

Osteopontin (OPN) is a phosphoglycoprotein that plays a role in bone remodeling, immune response and inflammation [129]. Le et al. [130] and Nordsmark et al. [25] were able to show an inverse relationship between plasma osteopontin and $\mathrm{pO}_{2}$ in $\mathrm{HNC}$ patients but no correlation between tumor osteopontin (obtained through immunohistochemical staining) and $\mathrm{pO}_{2}$ levels. A year earlier, Bache et al [131] found a correlation between osteopontin immunoreactivity, HIF-1alpha, Hb and VEGF but not with $\mathrm{pO}_{2}$ or CA-IX. They also found no correlation between HIF-1alpha, CA-IX and $\mathrm{pO}_{2}$. Overgaard et al. [132] used data from 320 patients from the Danish Head and Neck Cancer Group (DAHANCA) and found that high concentrations of plasma osteopontin predicted poor outcome but this could be attenuated when the patients were treated with nimorazole, a hypoxia radiosensitizer, during radiotherapy. Lim et al. [133] analysed data from 578 HNSCC patients (Trans Tasman Radiation Oncology Group: TROG study) and found no correlation between OPN and poor survival nor did they find any effect with the tumor radiosensitizer tirapazamine. It is not clear why these results are so different to those found in the DAHANCA study, though the TROG study appeared to be more stringent in their analysis, and the blood samples used in the DAHANCA study had been stored for nearly 19 years, while those used in the TROG study were fresh. Osteopontin secretion furthermore showed no correlation with hypoxia in 4 nasopharyngeal cancer cell lines [134]. Plasma osteopontin levels in metastatic nasopharyngeal carcinoma patients and HNSCC patients were elevated compared to controls and were a significant predictor of response to radiotherapy [134]. Tumor hypoxia increases metastasis and Courter et al. [129] found that osteopontin regulates tumor growth and metastasis by inhibiting apoptosis.

Low-grade inflammation as is evident in diabetes and metabolic syndrome has been associated with osteopontin derived from macrophages. Ahmad et al. [135] found a positive correlation between circulating osteopontin, fasting blood glucose and BMI. Smoking increases plasma osteopontin in type 2 diabetic patients [136]. The evidence correlating both serum and tumor osteopontin with tumor hypoxia and survival is mostly supportive, however some contradictory evidence mandates further research-

\section{Nitric Oxide and tumor hypoxia}

Nitric oxide is a free radical and an important signaling molecule involved in vasodilation and in protection against ischemic damage. Both salivary and serum nitric oxide can be used to determine oral mucosal disease, as well as oral precancer and cancer status in 
Table 1: Inflammatory biomarkers related to head and neck tumors and tumor hypoxia

\begin{tabular}{|c|c|c|c|c|}
\hline Biomarker & $\begin{array}{l}\text { Material } \\
\text { tested }\end{array}$ & Method & Result interpretation & Reference \\
\hline $\begin{array}{l}\text { CD8 (Tumor Infiltrating } \\
\text { Lymphocytes) }\end{array}$ & tumor & *IHC & $\begin{array}{l}\text { High CD8+TIL (HPV positive tonsillar } \\
\text { and base of tongue SCC) = better survival }\end{array}$ & {$[179]$} \\
\hline $\begin{array}{l}\text { CD44 (Tumor Infiltrating } \\
\text { Lymphocytes) }\end{array}$ & tumor & $\mathrm{IHC}$ & $\begin{array}{l}\text { Low expression } \\
\text { oropharyngeal SCC })=\text { very high survival }\end{array}$ & {$[180]$} \\
\hline $\begin{array}{l}\text { IDO (Indoleamine } \\
2,3 \text {-dioxygenase) }\end{array}$ & tumor & IHC & $\begin{array}{l}\text { High tumoral (laryngeal SCC) expression } \\
=\text { poor outcome (inhibited local } \\
\text { immunity) }\end{array}$ & {$[181]$} \\
\hline PD1 (programmed death 1) & tumor & IHC & $\begin{array}{l}\text { High expression (HPVpos.HNSCC) } \\
=\text { good prognosis. It can be efficiently } \\
\text { blocked by anti-PD1 (melanoma, } \\
\text { colorectal and renal cancer) }\end{array}$ & {$[182]$} \\
\hline $\begin{array}{l}\text { MIF (Macrophage Inhibitory } \\
\text { Factor) }\end{array}$ & tumor & IHC & $\begin{array}{l}\text { Increased expression of MIF in tumor } \\
\text { cells \& TILs predicts improved patient } \\
\text { survival (nasopharyngeal carcinoma) }\end{array}$ & {$[183]$} \\
\hline IL-15 (Interleukin) & tumor & IHC & $\begin{array}{l}\text { High intratumoral expression }=\text { poor } \\
\text { clinical outcome (HNSCC) }\end{array}$ & {$[184]$} \\
\hline $\begin{array}{l}\text { TGF } \beta 1 \quad \text { (Transforming } \\
\text { growth factor } \beta \text { 1) }\end{array}$ & tumor & IHC & $\begin{array}{l}\text { Overexpression might predict oral cancer } \\
\text { metastasis }\end{array}$ & {$[185]$} \\
\hline $\begin{array}{l}\text { SMAD } 6 \text { \& } 7 \text { (regulators of } \\
\text { TGF } \beta \text { pathway) }\end{array}$ & tumor & IHC & $\begin{array}{l}\text { Loss of expression }=\text { poor prognosis } \\
(\text { HNSCC) }\end{array}$ & {$[186]$} \\
\hline $\begin{array}{l}\text { CSF1R (Colony stimulating } \\
\text { factor } 1 \text { receptor) }\end{array}$ & tumor & IHC & $\begin{array}{l}\text { Up-regulated in radiation-resistant } \\
\text { HNSCC }\end{array}$ & {$[187]$} \\
\hline $\begin{array}{l}\text { MALT1 (Mucosa-associated } \\
\text { lymphoid tissue 1) }\end{array}$ & tumor & $\mathrm{IHC}$ & $\begin{array}{l}\text { Loss of expression }=\text { poor prognosis (oral } \\
\text { cancer) }\end{array}$ & {$[188]$} \\
\hline $\begin{array}{l}\text { CXCR4, also known as } \\
\text { SDF-1 }\end{array}$ & tumor & $\mathrm{IHC}$ & $\begin{array}{l}\text { High expression }=\text { poor prognosis } \\
\text { (tongue cancer) }\end{array}$ & {$[189]$} \\
\hline ArginaseII & tumor & IHC & $\begin{array}{l}\text { Absence of expression }=\text { prolonged } \\
\text { overall survival (HNSCC) }\end{array}$ & {$[190]$} \\
\hline
\end{tabular}

*IHC: Immunohistochemistry

patients [137-140]. NO is synthesized by nitric oxide synthase of which three isoforms are known, namely, inducible (iNOS), neuronal (nNOS) and endothelial (eNOS) nitric oxide synthase. It appears that the activity of VEGF may be upregulated by NO generation by eNOS and thus be implicated in tumor growth[96]. iNOS has also been shown to be a HIF target [141]. The role of NO in neovascularisation has already been discussed.

Despite significant complexities, current evidence supports NO as a prognostic marker and it has been shown to induce non-oxygen dependent HIF stimulation. Although increased NO is linked to poor outcome in cancer patients, NO has been shown to significantly increase cell apoptosis via p53 expression [142].

\section{p53 and tumor hypoxia}

p53 is a tumor suppressor protein encoded by the TP53 gene in humans. It is activated by a myriad of stressors, one of which is oxidative stress. In a mouse model DM2, a protein encoded by the DM2 gene inhibits p53 by transporting it from the nucleus to the cytosol or by attaching ubiquitin to p53 so that it can be degraded. Adduri et al. [143] found that p53 nuclear stabilization differed between 'old' and 'young' patients with squamous cell carcinoma of the tongue, being lower in 'older' 
Table 2: Genetic biomarkers related to head and neck tumors and tumor hypoxia

\begin{tabular}{|c|c|c|c|c|}
\hline Biomarker & $\begin{array}{l}\text { Material } \\
\text { tested }\end{array}$ & Method & Result interpretation & Reference \\
\hline $\begin{array}{l}\text { PTEN (Phosphatase and } \\
\text { Tensin homolog) }\end{array}$ & tumor & $* \mathrm{IHC}$ & $\begin{array}{l}\text { High expression in HNSCC = } \\
\text { significant gain in loco-regional control }\end{array}$ & {$[191]$} \\
\hline $\begin{array}{l}\text { mTOR (mechanistic } \\
\text { Target of Rapamycin) }\end{array}$ & tumor & IHC & \begin{tabular}{|l}
$\begin{array}{l}\text { High expression } \\
\text { (laryngeal cancer) }\end{array}$ \\
\end{tabular} & {$[192]$} \\
\hline $\begin{array}{lr}\text { PK-M2 \& } & \text { PK-M1 } \\
(\text { Pyruvate } & \text { kinase } \\
\text { isozymes } & \text { M1/M2) }\end{array}$ & tumor & $\mathrm{IHC}$ & $\begin{array}{l}\text { Isoform switch to higher expression of } \\
\text { PK-M2 = poor prognosis (HNSCC) }\end{array}$ & {$[193]$} \\
\hline integrin $\alpha v \beta 5$ & tumor & $\mathrm{IHC}$ & \begin{tabular}{|lll} 
High expression $=$ high risk of \\
metastasis (Laryngeal SCC)
\end{tabular} & {$[194]$} \\
\hline \begin{tabular}{|lr} 
PDK-1 & (Pyruvate \\
dehydrogenase kinase-1)
\end{tabular} & tumor & $\mathrm{IHC}$ & $\begin{array}{l}\text { High expression }=\text { poor prognosis } \\
(\text { HNSCC) }\end{array}$ & {$[195]$} \\
\hline Ki-67 & tumor & $\mathrm{IHC}$ & $\begin{array}{l}\text { High expression }=\text { good prognosis } \\
\text { (Oral SCC) }\end{array}$ & {$[196]$} \\
\hline $\mathrm{p} 27$ & tumor & IHC & $\begin{array}{l}\text { High expression }=\text { good response } \\
\text { of HNSCC to } \\
(\text { Cisplatin }+5 \mathrm{FU})\end{array}$ & {$[197]$} \\
\hline $\begin{array}{l}\text { EGFR (epidermal growth } \\
\text { factor receptor) }\end{array}$ & tumor & $\mathrm{IHC}$ & $\begin{array}{l}\text { High expression predicts better } \\
\text { loco-reg. control of HNSCC with } \\
\text { Contin. Hyperfract. Acceler. Radioth. } \\
\text { (CHART) }\end{array}$ & {$[198]$} \\
\hline LOX (Lysyl oxidase) & tumor & $\mathrm{IHC}$ & $\begin{array}{l}\text { High expression }=\text { poor overall survival } \\
\text { (HNSCC) }\end{array}$ & {$[199]$} \\
\hline *DSPP, OPN, MMP-9 & tumor & $\mathrm{IHC}$ & $\begin{array}{l}\text { Expression in negative tumor margins } \\
\text { predict recurrence of oral cancer }\end{array}$ & {$[200]$} \\
\hline $\begin{array}{l}\text { MMP-13 (Matrix } \\
\text { metalloproteinase-13) }\end{array}$ & tumor & IHC & $\begin{array}{l}\text { high nuclear MMP-13 expression }= \\
\text { poor outcome (tongue cancer) }\end{array}$ & {$[201]$} \\
\hline $\begin{array}{l}\text { CytK13, CytK } 14 \text { and } \\
\text { CytK } 16 \text { (Cytokeratins) }\end{array}$ & tumor & IHC & $\begin{array}{l}\text { Loss or downregulation }=\text { poor } \\
\text { prognosis (recurrence \& metastasis of } \\
\text { tongue cancer) }\end{array}$ & {$[202]$} \\
\hline CytK19 (Cytokeratin 19) & tumor & $\mathrm{IHC}$ & \begin{tabular}{|l}
$\begin{array}{l}\text { Decreased in tumor: metastasis } \\
\text { (HNSCC) }\end{array}$ \\
\end{tabular} & {$[203]$} \\
\hline $\begin{array}{l}\text { Slug (necessary for HIF- } \\
1 \alpha \text { induced cadherin } \\
\text { switch) }\end{array}$ & tumor & IHC & $\begin{array}{l}\text { High expression }=\text { tumor invasion and } \\
\text { short survival }(\text { HNSCC) }\end{array}$ & {$[204]$} \\
\hline \begin{tabular}{lcc|} 
HDAC2 & $\&$ & pVHL \\
(Histone & deacetylase 2 \\
$\&$ von & Hippel-Lindau \\
protein) & &
\end{tabular} & tumor & IHC & $\begin{array}{l}\text { High HDAC2 \& low VHL expression } \\
=\text { advanced stage and poor prognosis } \\
\text { (Oral SCC) }\end{array}$ & {$[205,206]$} \\
\hline $\begin{array}{l}\text { CTGF (Connective } \\
\text { Tissue Growth Factor) } \\
\end{array}$ & tumor & IHC & $\begin{array}{l}\text { High expression }=\text { poor prognosis } \\
(\text { HNSCC) }\end{array}$ & {$[207]$} \\
\hline Galectin 1 and 3 & tumor & IHC & $\begin{array}{l}\text { High expression correlates with tongue } \\
\text { SCC metastasis }\end{array}$ & {$[208]$} \\
\hline
\end{tabular}

* IHC: Immunohistochemistry; DSPP: dentinsialophosphoprotein; OPN: osteopontin; MMP-9: matrix metalloproteinase-9 $[70]$

patients. Both p53 nuclear stabilization and p53 mutations were correlated with poor survival in the patients. Persistent expression of wild type p53 can be seen as a positive predictor for radiosensitivity [144]. This is in contrast to Portugal et al. [145] who found no correlation between p53 gene mutation and recurrence or survival status but who did, however, find a correlation between p53 gene mutation and alcohol use. The correlation of p53 gene mutation and alcohol-use corroborated the results of Sorensen et al. [146] who found that non-smoking, non- drinking young patients with squamous cell carcinoma of the tongue had less p53 mutations than their counterparts. As mentioned earlier, alcohol and cigarette use are independent prognostic factors for poor survival.

Thus far it has been thought that inhibiting the MDM2/HIF-1alpha interaction would result in tumor cell death in hypoxia [147] but recently Joshi et al. [84] found that MDM2 causes HIF-1alpha to be degraded during hypoxia so inhibiting the MDM2/HIF-1alpha interaction may actually result in tumor growth, not death. The role of 
p53 and its mutations can be regarded as well established in HNSCC, however its precise interrelationship with tumor hypoxia needs to be explored and clarified further.

Genetic regulation and interplay in cancer is demonstrated by the extensive research on microRNAs.

\section{MicroRNAs and tumor hypoxia}

MicroRNA (miRNAs) are short noncoding RNAs that posttranscriptionally regulate target messenger RNAs [148]. 7 microRNAs are consistently upregulated in HNSCC, namely, miR-21, miR-7, miR-155, miR-130b, miR-223, miR-34b, miR-210 and 4 are consistently downregulated, namely, miR-100, miR-99a, miR-125b, and miR-375 [149]. We will mainly take a closer look at miR-21, miR-210 and miR-375.

miR-21 which is the most researched miRNA, is upregulated in various cancers [150]. It is anti-apoptotic and is expressed in the tumor stroma of HNSCC tumors [148]. Gee et al. [15] could find no correlation between miR-21 and other markers for tumor hypoxia in HNSCC patients. In vitro, Polytarchou et al. [151] found that Akt2 promotes hypoxia resistance via upregulated miR21 whereas Loayza-Puch [152] found that hypoxia downregulates RECK (a tumor-suppressor protein) via upregulated miR-21.

miR-210 is consistently induced by hypoxia as a HIF target in normal and transformed cells [153]. It correlates with markers of tumor hypoxia in HNSCC patients, such as HIF-1alpha, CA-IX and a 99-gene hypoxia metagene [15]. To our knowledge, miR-210 is only regulated by hypoxia.

miR-375 is downregulated in HNSCC alluding to it being a tumor suppressor. Possible target genes of miR375 are those involved in cell growth and insulin secretion [154]. Congruent with its effect on insulin secretion, high levels of miR-375 correlate with the incidence of diabetes and miR-375 has been suggested as a biomarker for not only cancer $[155,156]$ but Type 2 diabetes as well [157]. Overexpressing miR-375 in vitro in laryngeal cancer cell lines (SNU-48 and SNU-899) resulted in increased apoptosis and decreased proliferation and invasivity [158] which fits with the evidence that miR-375 acts via phosphoinositide-dependent protein kinase-1 [159]. miR375 correlates to tumor staging and tumor size but no experiments were done regarding tumor hypoxia directly [160].

Although miRNAs look promising as biomarkers for HNSCC, they are regulated by various cancers and diseases and their role in tumor hypoxia needs further elucidation. Table 1 and Table 2 depict a further list of possible inflammatory and genetic biomarkers relevant to $\mathrm{HNC}$ as found in the current literature.

\section{Genetic profiling}

Various efforts have been made to define and utilize genetic head and neck tumor profiling. A number of gene expression subtypes can be identified nanely basal (31\%), mesenchymal (27\%), atypical (24\%) and classical $(18 \%)$. Some promising findings have been forthcoming and further research is needed to elucidate their potential clinical relevance.

For example, it was shown that the NFE2L2 oxidative stress pathway is a tobacco-related signature not specific to an anatomic tumor site. HPV-positive tumors show recurrent deletions and mutations of TNF receptor associated factor 3 gene loss as well as mutations in exon 9 of the PIK3CA helicase domain. Tumor cause can now thus be confirmed genetically [60]. A 26 gene hypoxia signature has been used used to calculate a hypoxia score to predict treatment benefit for a hypoxia adapted treatment with carbogen and nicotinamide protocol before radiotherapy in 157 larynx cancer patients. High expression of hypoxia related genes did predict for a poorer 5 year survival however not for the value of hypoxia modification treatment [161]. In an attempt so simplify further, clinically relevant research, smaller, more robust signatures or metagenes have been developed [162, 163].

Tourstup $\mathrm{K}$ et al.[155, 156]developed a 15 gene hypoxia classifier with prognostic impact that was verified it in the DAHANCA 5 study cohort and is now being implemented in a prospective accelerated chemoradiotherapy trial with or without the radiosensitizer nimorazole in HPV negative HNSCC patients (EORTC 1219).

\section{Imaging}

Imaging may be a possible alternative to profiling tumor hypoxia. [F-18] fluoromisoni-dazole (FMISO), (18)F-fluoroazomycin arabinoside (FAZA)-PET, dynamic contrast enhanced MRI , arterial spin labelling (ASL) MRI and other MRI techniques have all shown promise in this regard, and may allow hypoxic tumors to be defined in a non- invasive and possibly continuous manner. Imaging may even allow us to monitor treatment response [164168]. Near infra-red spectrometry may be a solution to predict oxygen content in more superficial tumors[169]. The major drawback of imaging thus far has been the lack of research proven correlation of the imaging to the various hypoxia parameters.

\section{DISCUSSION}

HNC comprises many different cancers in terms of aetiology, localization, duration, size, metastatic potential etc., yet in many analyses these diverse malignancies 
are often grouped together that could lead to erroneous conclusions. It may therefore be more prudent to deal with each cancer separately and define the mechanisms and treatment separately, then again this further subtyping will further much needed diminish statistical power [89, 170-172]. As a common denominator all these cancers are linked by tumor hypoxia as a prognostic factor, however the molecular pathways involved may be different and therefore treatments need to be more individualized. As described tumor hypoxia is only universal in terminology, but extremely diverse in term of definition as the measuring parameters range from physical measurement to various up and downstream metabolic products.

HIF-1alpha, CA-IX and Glut1 are used as the main markers to represent tumor hypoxia, but they fall short of the criteria for a true endogenous marker as listed by Janssen et al. [3]. These markers can, however, potentially be used to predict disease progression or overall survival, but independently of hypoxia as especially HIF is also influenced by non hypoxic driven factors. Imaging techniques such as FMISO, FAZA-PET and various MRI techniques such as arterial spin labeling, BOLD-MRI and quantitative diffusion MRI will probably lead the way to non invasive hypoxia measurements, but the metabolic interpretation will have to be validated with the various biomarkers as discussed [167, 173-175].

HPV, with HPV E7 being a known HIF-1alpha protein interactor [54], is becoming one of the main risk factors for HNSCC. Specifically oropharyngeal cancer with smoking acting as an compounding risk factor with the risk of death increasing steadily with every additional packyear [176]. Even though HPV-infected cancers are aggressive and grow rapidly, prognosis is generally good whereas tumor hypoxia in both HPV-positive and negative tumors results in poorer prognosis [177]. Does the answer to the differences in outcome lie in individualised immune response? Inflammation is known to play a role in tumor hypoxia but the role of inflammation in HPV-positive cancer is still unclear. Can the differences be attributed to the difference in the miRNA profile as suggested by Lajer et al. [178]?

There is no real standardization between clinical trials in terms of parameters set, e.g. the hemoglobin cut-off to determine anemia varies, $\mathrm{pO}_{2}$ as parameter for hypoxia varies and the term tumor hypoxia is erroneously used as a collective term for what should be called tumor oxygenation. It is therefore, surely not sufficient to look at a single marker for hypoxia but rather one probably needs several as shown by Hsieh et al. [116].

Despite the above outlined limitations in some of the understandings of tumor hypoxia, there are centres implementing adapted radiation protocols as standard of care $[24,25]$.

As genetic profiling develops, the intricacies of the complex tumor hypoxia drama may be unraveled further, however it may also deepen the plot with hundreds of new key suspects arising, each playing a supporting role to the main role player, oxygen. Despite the ever expanding complex plot, there have been some positive discoveries with potential therapeutic relevance, like HIF-1alpha. This will pave the way for more individualized treatment, however, much more needs to be uncovered to be able to routinely follow and adapt treatment response.

\section{ACKNOWLEDGMENTS}

Thank you to Mrs. Ruth Gottmann for the artwork and to Prof. R. Wenger for comments and insightful discussions regarding the review.

\section{CONFLICT OF INTEREST}

The authors declare no conflict of interest.

\section{FUNDING}

This work was supported by the CRPP Tumor Oxygenation Project of the University Hospital of Zürich.

\section{REFERENCES}

1. Ferlay J, Soerjomataram I, Dikshit R, Eser S, Mathers C, Rebelo M, Parkin DM, Forman D and Bray F. Cancer incidence and mortality worldwide: sources, methods and major patterns in GLOBOCAN 2012. International journal of cancer. 2015; 136(5):E359-386.

2. Maasland DH, van den Brandt PA, Kremer B, Goldbohm RA and Schouten LJ. Alcohol consumption, cigarette smoking and the risk of subtypes of head-neck cancer: results from the Netherlands Cohort Study. BMC cancer. 2014; 14:187.

3. Janssen HL, Haustermans KM, Balm AJ and Begg AC. Hypoxia in head and neck cancer: how much, how important? Head \& neck. 2005; 27(7):622-638.

4. Isa AY, Ward TH, West CM, Slevin NJ and Homer JJ. Hypoxia in head and neck cancer. Br J Radiol. 2006; 79(946):791-798.

5. Kumar P. Impact of anemia in patients with head and neck cancer. Oncologist. 2000; 5 Suppl 2:13-18.

6. Ebbesen P, Pettersen EO, Gorr TA, Jobst G, Williams K, Kieninger J, Wenger RH, Pastorekova S, Dubois L, Lambin P, Wouters BG, Van Den Beucken T, Supuran CT, Poellinger L, Ratcliffe P, Kanopka A, et al. Taking advantage of tumor cell adaptations to hypoxia for developing new tumor markers and treatment strategies. Journal of Enzyme Inhibition \& Medicinal Chemistry. 2009; 24 Suppl 1:1-39.

7. Rischin D, Hicks RJ, Fisher R, Binns D, Corry J, Porceddu S, Peters LJ and Trans-Tasman Radiation Oncology Group S. Prognostic significance of $[18 \mathrm{~F}]$-misonidazole positron 
emission tomography-detected tumor hypoxia in patients with advanced head and neck cancer randomly assigned to chemoradiation with or without tirapazamine: a substudy of Trans-Tasman Radiation Oncology Group Study 98.02. J Clin Oncol. 2006; 24(13):2098-2104.

8. Kaanders JH, Wijffels KI, Marres HA, Ljungkvist AS, Pop LA, van den Hoogen FJ, de Wilde PC, Bussink J, Raleigh JA and van der Kogel AJ. Pimonidazole binding and tumor vascularity predict for treatment outcome in head and neck cancer. Cancer Res. 2002; 62(23):7066-7074.

9. Rademakers SE, Span PN, Kaanders JH, Sweep FC, van der Kogel AJ and Bussink J. Molecular aspects of tumour hypoxia. Molecular oncology. 2008; 2(1):41-53.

10. Bose P, Brockton NT and Dort JC. Head and neck cancer: from anatomy to biology. International journal of cancer. 2013; 133(9):2013-2023.

11. Vaupel P, Mayer A and Hockel M. Tumor hypoxia and malignant progression. Methods Enzymol. 2004; 381:335354.

12. Luoto KR, Kumareswaran, R., Bristow, R.G. Tumor hypoxia as a driving force in genetic instability. Genome Integr. 2013; 4.

13. Vaupel P, Kallinowski F and Okunieff P. Blood flow, oxygen and nutrient supply, and metabolic microenvironment of human tumors: a review. Cancer Res. 1989; 49(23):6449-6465.

14. Cao Y, Li CY, Moeller BJ, Yu D, Zhao Y, Dreher MR, Shan S and Dewhirst MW. Observation of incipient tumor angiogenesis that is independent of hypoxia and hypoxia inducible factor-1 activation. Cancer Res. 2005; 65(13):5498-5505.

15. Gee HE, Camps C, Buffa FM, Patiar S, Winter SC, Betts G, Homer J, Corbridge R, Cox G, West CM, Ragoussis J and Harris AL. hsa-mir-210 is a marker of tumor hypoxia and a prognostic factor in head and neck cancer. Cancer. 2010; 116(9):2148-2158.

16. Hoogsteen IJ, Marres HA, Bussink J, van der Kogel AJ and Kaanders JH. Tumor microenvironment in head and neck squamous cell carcinomas: predictive value and clinical relevance of hypoxic markers. A review. Head \& neck. 2007; 29(6):591-604.

17. Hoogsteen IJ, Marres HA, van der Kogel AJ and Kaanders JH. The hypoxic tumour microenvironment, patient selection and hypoxia-modifying treatments. Clinical oncology. 2007; 19(6):385-396.

18. Chan DA and Giaccia AJ. Hypoxia, gene expression, and metastasis. Cancer metastasis reviews. 2007; 26(2):333339.

19. Bayer $\mathrm{C}$ and Vaupel P. Acute versus chronic hypoxia in tumors: Controversial data concerning time frames and biological consequences. Strahlentherapie und Onkologie. 2012; 188(7):616-627.

20. Brown JM and Giaccia AJ. The unique physiology of solid tumors: opportunities (and problems) for cancer therapy.
Cancer Res. 1998; 58(7):1408-1416.

21. Al-Zhoughbi W. HJ, Paramasivan S.G., Till H., Pichler M., Guertl-Lackner B and Hoeflera G. Tumor macroenvironment and metabolism. Semin Oncol. 2014; 41:281--295.

22. Dietl B, Marienhagen J, Schafer C and Kolbl O. The prognostic value of anaemia at different treatment times in patients with locally advanced head and neck cancer treated with surgery and postoperative radiotherapy. Clinical oncology. 2007; 19(4):228-233.

23. van de Pol SM, Doornaert PA, de Bree R, Leemans CR, Slotman BJ and Langendijk JA. The significance of anemia in squamous cell head and neck cancer treated with surgery and postoperative radiotherapy. Oral oncology. 2006; 42(2):131-138.

24. Nordsmark M, Bentzen, S.M., Rudat, V., Brizel, D., Lartigau, E., Stadler, P., Becker, A., Adam, M., Molls, M., Dunst, J., Terris, D.J., and Overgaard, J. Prognostic value of tumor oxygenation in 397 head nad neck tumors after primary radiation therapy. An international multi-center study. Radiotherapy and Oncology. 2005; 77:18--24.

25. Nordsmark M, Eriksen JG, Gebski V, Alsner J, Horsman MR and Overgaard J. Differential risk assessments from five hypoxia specific assays: The basis for biologically adapted individualized radiotherapy in advanced head and neck cancer patients. Radiotherapy and oncology. 2007; 83(3):389-397.

26. Littlewood TJ. The impact of hemoglobin levels on treatment outcomes in patients with cancer. Semin Oncol. 2001; 28(2 Suppl 8):49-53.

27. Huang M, Chen Q, Xiao J, Yao T, Bian L, Liu C and Lin Z. Overexpression of hypoxia-inducible factor-1alpha is a predictor of poor prognosis in cervical cancer: a clinicopathologic study and a meta-analysis. Int J Gynecol Cancer. 2014; 24(6):1054-1064.

28. Upile T, Jerjes W, Sandison A, Singh S, Rhys-Evans P, Sudhoff $\mathrm{H}$ and Hopper C. The direct effects of stored blood products may worsen prognosis of cancer patients; shall we transfuse or not? An explanation of the adverse oncological consequences of blood product transfusion with a testable hypothesis driven experimental research protocol. Med Hypotheses. 2008; 71(4):489-492.

29. Bhide SA, Ahmed M, Rengarajan V, Powell C, Miah A, Newbold K, Nutting CM and Harrington KJ. Anemia during sequential induction chemotherapy and chemoradiation for head and neck cancer: the impact of blood transfusion on treatment outcome. International journal of radiation oncology, biology, physics. 2009; 73(2):391-398.

30. Hoff CM, Lassen P, Eriksen JG, Hansen HS, Specht L, Overgaard M, Grau C, Johansen J, Bentzen J, Andersen L, Evensen JF and Overgaard J. Does transfusion improve the outcome for HNSCC patients treated with radiotherapy? - results from the randomized DAHANCA 5 and 7 trials. Acta oncologica. 2011; 50(7):1006-1014. 
31. Vaupel P, Thews O, Mayer A, Hockel S and Hockel M. Oxygenation status of gynecologic tumors: what is the optimal hemoglobin level? Strahlentherapie und Onkologie. 2002; 178(12):727-731.

32. Knocke T-H, Weitmann, H-D., Feldmann, H-J., Selzer, E., and Pötter, R. Intratumoral pO2-measurements as predictive assay in the treatment of carcinoma of the uterine cervix. Radiotherapy and Oncology. 1999; 53(2):99-104.

33. Janssens GO, Rademakers SE, Terhaard CH, Doornaert PA, Bijl HP, van den Ende P, Chin A, Takes RP, de Bree R, Hoogsteen IJ, Bussink J, Span PN and Kaanders JH. Improved recurrence-free survival with ARCON for anemic patients with laryngeal cancer. Clinical cancer research. 2014; 20(5):1345-1354.

34. Henke M, Guttenberger R, Barke A, Pajonk F, Potter R and Frommhold H. Erythropoietin for patients undergoing radiotherapy: a pilot study. Radiotherapy and oncology. 1999; 50(2):185-190.

35. Henke M, Laszig R, Rube C, Schafer U, Haase KD, Schilcher B, Mose S, Beer KT, Burger U, Dougherty C and Frommhold H. Erythropoietin to treat head and neck cancer patients with anaemia undergoing radiotherapy: randomised, double-blind, placebo-controlled trial. Lancet. 2003; 362(9392):1255-1260.

36. Glaser CM, Millesi W, Kornek GV, Lang S, Schull B, Watzinger F, Selzer E and Lavey RS. Impact of hemoglobin level and use of recombinant erythropoietin on efficacy of preoperative chemoradiation therapy for squamous cell carcinoma of the oral cavity and oropharynx. Int J Radiat Oncol. 2001; 50(3):705-715.

37. Lo Nigro C, Maffi M, Fischel JL, Monteverde M, Catarsi P, Tonissi F, Lattanzio L, Riba M, Etienne-Grimaldi MC, Formento P, Milano G and Merlano M. Impact of erythropoietin on the effects of irradiation under hypoxia. Journal of cancer research and clinical oncology. 2009; 135(11):1615-1623.

38. Sasaki Y, Kjellen E, Mineta H, Wennerberg J and Ekblad L. No direct effects of erythropoietin beta on a head and neck squamous cell carcinoma cell line which is growth stimulated in vivo. Acta oncologica. 2009; 48(7):10621069.

39. Koukourakis MI, Giatromanolaki A, Sivridis E, Pastorek J, Karapantzos I, Gatter KC, Harris AL, Tumour and Angiogenesis Research G. Hypoxia-activated tumor pathways of angiogenesis and $\mathrm{pH}$ regulation independent of anemia in head-and-neck cancer. International journal of radiation oncology, biology, physics. 2004; 59(1):67-71.

40. Winter SC, Shah KA, Han C, Campo L, Turley H, Leek R, Corbridge RJ, Cox GJ and Harris AL. The relation between hypoxia-inducible factor (HIF)-1alpha and HIF-2alpha expression with anemia and outcome in surgically treated head and neck cancer. Cancer. 2006; 107(4):757-766.

41. Overgaard J, Nielsen JE and Grau C. Effect of carboxyhemoglobin on tumor oxygen unloading capacity in patients with squamous cell carcinoma of the head and neck. International journal of radiation oncology, biology, physics. 1992; 22(3):407-410.

42. Browman GP, Wong G, Hodson I, Sathya J, Russell R, McAlpine L, Skingley $P$ and Levine MN. Influence of cigarette smoking on the efficacy of radiation therapy in head and neck cancer. N Engl J Med. 1993; 328(3):159163.

43. Hoff CM, Grau C and Overgaard J. Effect of smoking on oxygen delivery and outcome in patients treated with radiotherapy for head and neck squamous cell carcinoma-a prospective study. Radiotherapy and oncology. 2012; 103(1):38-44.

44. Siemann DW, Hill RP and Bush RS. Smoking: the influence of carboxyhemoglobin ( $\mathrm{HbCO}$ ) on tumor oxygenation and response to radiation. International journal of radiation oncology, biology, physics. 1978; 4(7-8):657-662.

45. Grau C, Horsman MR and Overgaard J. Influence of carboxyhemoglobin level on tumor growth, blood flow, and radiation response in an experimental model. International journal of radiation oncology, biology, physics. 1992; 22(3):421-424.

46. Martin JW, Mousa SS, Shaker O and Mousa SA. The multiple faces of nicotine and its implications in tissue and wound repair. Experimental dermatology. 2009; 18(6):497505.

47. Guo L, Li L, Wang W, Pan Z, Zhou Q and Wu Z. Mitochondrial reactive oxygen species mediates nicotineinduced hypoxia-inducible factor-1alpha expression in human non-small cell lung cancer cells. Biochimica et biophysica acta. 2012; 1822(6):852-861.

48. Shi D, Guo W, Chen W, Fu L, Wang J, Tian Y, Xiao X, Kang T, Huang W and Deng W. Nicotine promotes proliferation of human nasopharyngeal carcinoma cells by regulating alpha7AChR, ERK, HIF-1alpha and VEGF/ PEDF signaling. PloS one. 2012; 7(8):e43898.

49. Zhou JY, Jiang ZA, Zhao CY, Zhen Z, Wang W and Nanji AA. Long-term binge and escalating ethanol exposure causes necroinflammation and fibrosis in rat liver. Alcoholism, clinical and experimental research. 2013; 37(2):213-222.

50. Reidy J, McHugh E and Stassen LF. A review of the relationship between alcohol and oral cancer. The surgeon. 2011; 9(5):278-283.

51. Lieber CS, Baraona E, Hernandez-Munoz R, Kubota S, Sato N, Kawano S, Matsumura T and Inatomi N. Impaired oxygen utilization. A new mechanism for the hepatotoxicity of ethanol in sub-human primates. The Journal of clinical investigation. 1989; 83(5):1682-1690.

52. Nakamura M, Bodily JM, Beglin M, Kyo S, Inoue M and Laimins LA. Hypoxia-specific stabilization of HIF-1alpha by human papillomaviruses. Virology. 2009; 387(2):442448.

53. Guo Y, Meng X, Ma J, Zheng Y, Wang Q, Wang Y and Shang H. Human papillomavirus 16 E6 contributes HIF- 
1alpha induced Warburg effect by attenuating the VHLHIF-1alpha interaction. International journal of molecular sciences. 2014; 15(5):7974-7986.

54. Rodolico V, Arancio W, Amato MC, Aragona F, Cappello F, Di Fede O, Pannone G and Campisi G. Hypoxia inducible factor-1 alpha expression is increased in infected positive HPV16 DNA oral squamous cell carcinoma and positively associated with HPV16 E7 oncoprotein. Infectious agents and cancer. 2011; 6(1):18.

55. Hong A, Zhang M, Veillard AS, Jahanbani J, Lee CS, Jones D, Harnett G, Clark J, Elliott M, Milross C and Rose B. The prognostic significance of hypoxia inducing factor 1-alpha in oropharyngeal cancer in relation to human papillomavirus status. Oral oncology. 2013; 49(4):354-359.

56. Bogusiak K and Kobos J. The role of human papillomavirus infection in the head and neck region and methods for its detection. Pol J Pathol. 2014; 65(1):1-14.

57. Janssen HL, Haustermans KM, Sprong D, Blommestijn G, Hofland I, Hoebers FJ, Blijweert E, Raleigh JA, Semenza GL, Varia MA, Balm AJ, van Velthuysen ML, Delaere $\mathrm{P}$, Sciot R and Begg AC. HIF-1A, pimonidazole, and iododeoxyuridine to estimate hypoxia and perfusion in human head-and-neck tumors. International journal of radiation oncology, biology, physics. 2002; 54(5):15371549.

58. Trinkaus ME, Hicks RJ, Young RJ, Peters LJ, Solomon B, Bressel M, Corry J, Fisher R, Binns D, McArthur GA and Rischin D. Correlation of p16 status, hypoxic imaging using [18F]-misonidazole positron emission tomography and outcome in patients with loco-regionally advanced head and neck cancer. Journal of medical imaging and radiation oncology. 2014; 58(1):89-97.

59. Mortensen LS, Johansen J, Kallehauge J, Primdahl H, Busk M, Lassen P, Alsner J, Sorensen BS, Toustrup K, Jakobsen $\mathrm{S}$, Petersen J, Petersen H, Theil J, Nordsmark M and Overgaard J. FAZA PET/CT hypoxia imaging in patients with squamous cell carcinoma of the head and neck treated with radiotherapy: results from the DAHANCA 24 trial. Radiotherapy and oncology. 2012; 105(1):14-20.

60. Cancer Genome Atlas N. Comprehensive genomic characterization of head and neck squamous cell carcinomas. Nature. 2015; 517(7536):576-582.

61. Balkwill $\mathrm{F}$ and Mantovani A. Inflammation and cancer: back to Virchow? Lancet. 2001; 357(9255):539-545.

62. Coussens LM and Werb Z. Inflammation and cancer. Nature. 2002; 420(6917):860-867.

63. Bonomi M, Patsias A, Posner M and Sikora A. The role of inflammation in head and neck cancer. Advances in experimental medicine and biology. 2014; 816:107-127.

64. Bernstein JM, Bernstein CR, West CM and Homer JJ. Molecular and cellular processes underlying the hallmarks of head and neck cancer. European archives of oto-rhinolaryngology. 2013; 270(10):2585-2593.

65. Wittekindt C, Wagner S, Mayer CS and Klussmann
JP. [Basics of tumor development and importance of human papilloma virus (HPV) for head and neck cancer]. Laryngorhinootologie. 2012; 91 Suppl 1:S1-26.

66. Csermely P, Hodsagi, J., Korcsmaros, T., Modos, D., PerezLopez, A.R., Szalay, K., Veres, D.V., Lenti, K., Wu, L.Y., Zhang, X.S. Cancer stem cells display extremely large evolvability: alternating plastic nad rigid networks as a potential mechanism: Network models, novel therapeutic target strategies, and the contributions of hypoxia, inflammation and cellular senescence. Semin Cancer Biol. 2014; 8:00130--00132.

67. Lee LT, Chen PH, Chang CT, Wang J, Wong YK and Wang HW. Quantitative physiology and immunohistochemistry of oral lesions. Biomed Opt Express. 2013; 4(11):2696-2709.

68. Clatot F, Gouerant S, Mareschal S, Cornic M, Berghian A, Choussy O, El Ouakif F, Francois A, Benard M, Ruminy $\mathrm{P}$, Picquenot JM and Jardin F. The gene expression profile of inflammatory, hypoxic and metabolic genes predicts the metastatic spread of human head and neck squamous cell carcinoma. Oral oncology. 2014; 50(3):200-207.

69. Albert S, Riveiro ME, Halimi C, Hourseau M, Couvelard A, Serova M, Barry B, Raymond E and Faivre S. Focus on the role of the CXCL12/CXCR4 chemokine axis in head and neck squamous cell carcinoma. Head \& neck. 2013; 35(12):1819-1828.

70. Dumitru CA, Bankfalvi A, Gu X, Zeidler R, Brandau S and Lang S. AHNAK and inflammatory markers predict poor survival in laryngeal carcinoma. PloS one. 2013; 8(2):e56420.

71. Rademakers SE, Lok J, van der Kogel AJ, Bussink J and Kaanders JH. Metabolic markers in relation to hypoxia; staining patterns and colocalization of pimonidazole, HIF1alpha, CAIX, LDH-5, GLUT-1, MCT1 and MCT4. BMC cancer. 2011; 11:167.

72. Airley RE, Loncaster J, Raleigh JA, Harris AL, Davidson SE, Hunter RD, West CM and Stratford IJ. GLUT-1 and CAIX as intrinsic markers of hypoxia in carcinoma of the cervix: relationship to pimonidazole binding. International journal of cancer. 2003; 104(1):85-91.

73. Jankovic B, Aquino-Parsons C, Raleigh JA, Stanbridge EJ, Durand RE, Banath JP, MacPhail SH and Olive PL. Comparison between pimonidazole binding, oxygen electrode measurements, and expression of endogenous hypoxia markers in cancer of the uterine cervix. Cytometry Part B, Clinical cytometry. 2006; 70(2):45-55.

74. Kimura H, Weisz A, Kurashima Y, Hashimoto K, Ogura T, D'Acquisto F, Addeo R, Makuuchi M and Esumi H. Hypoxia response element of the human vascular endothelial growth factor gene mediates transcriptional regulation by nitric oxide: control of hypoxia-inducible factor-1 activity by nitric oxide. Blood. 2000; 95(1):189197.

75. Kimura H, Weisz A, Ogura T, Hitomi Y, Kurashima Y, Hashimoto K, D'Acquisto F, Makuuchi M and Esumi H. Identification of hypoxia-inducible factor 1 ancillary 
sequence and its function in vascular endothelial growth factor gene induction by hypoxia and nitric oxide. The Journal of biological chemistry. 2001; 276(3):2292-2298.

76. Anavi S, Hahn-Obercyger M, Madar Z and Tirosh O. Mechanism for HIF-1 activation by cholesterol under normoxia: a redox signaling pathway for liver damage. Free radical biology \& medicine. 2014; 71:61-69.

77. Hsu CC, Wang $\mathrm{CH}$, Wu LC, Hsia CY, Chi CW, Yin $\mathrm{PH}$, Chang CJ, Sung MT, Wei YH, Lu SH and Lee HC. Mitochondrial dysfunction represses HIF-1alpha protein synthesis through AMPK activation in human hepatoma HepG2 cells. Biochimica et biophysica acta. 2013; 1830(10):4743-4751.

78. Shih SC and Claffey KP. Role of AP-1 and HIF-1 transcription factors in TGF-beta activation of VEGF expression. Growth factors. 2001; 19(1):19-34.

79. Rozen-Zvi B, Hayashida T, Hubchak SC, Hanna C, Platanias LC and Schnaper HW. TGF-beta/Smad3 activates mammalian target of rapamycin complex-1 to promote collagen production by increasing HIF-1alpha expression. Am J Physiol Renal Physiol. 2013; 305(4):F485-494.

80. Zelzer E, Levy Y, Kahana C, Shilo B-Z, Rubinstein M and Cohen B. Insulin induces transcription of target genes through the hypoxia-inducible factor HIF-1alpha/ARNT. The EMBO Journal. 1998; 17(17):5085-5094.

81. Carrera S, Senra J, Acosta MI, Althubiti M, Hammond EM, de Verdier PJ and Macip S. The Role of the HIF-1 alpha Transcription Factor in Increased Cell Division at Physiological Oxygen Tensions. PloS one. 2014; 9(5):e97938.

82. Stiehl DP, Wirthner R, Koditz J, Spielmann P, Camenisch $\mathrm{G}$ and Wenger RH. Increased prolyl 4-hydroxylase domain proteins compensate for decreased oxygen levels. Evidence for an autoregulatory oxygen-sensing system. The Journal of biological chemistry. 2006; 281(33):23482-23491.

83. Wijffels KI, Kaanders, J.H., Rijken, P.F., Bussink, J., van den Hoogen, F.J., Marres, H.A., de Wilde, P.C., Raleigh, J.A., van der Kogel, A.J. Vascular architecture and hypoxic profiles in human head and neck squamous cell carcinomas. Br J Cancer. 2000; 83(5 ):674--683.

84. Joshi S, Singh AR and Durden DL. MDM2 regulates hypoxic hypoxia-inducible factor 1alpha stability in an E3 ligase, proteasome, and PTEN-phosphatidylinositol 3-kinase-AKT-dependent manner. The Journal of biological chemistry. 2014; 289(33):22785-22797.

85. Suba Z and Ujpal M. Disorders of glucose metabolism and risk of oral cancer. Fogorv Sz. 2007; 100(5):250-257, 243259.

86. Ujpal M, Matos, O., Bibok, G., Somogyi, A., Szabo, G., Suba, Z. Diabetes and oral tumors in Hungary. Diabetes Care. 2004; 27:770--774.

87. Watanabe S, Kato, M., Kotani, I., Ryoke, K., Hayashi, K. Lymphatic vessel density and vascular endothelial growth factor expression in squamous cell carcinomas of lip and oral cavity: A clinicopathological analysis with immunohistochemistry using antibodies to D2-40, VEGF-C and VEGF-D. Yonago Acta Med. 2013; 56:29--37.

88. Shang ZJ, Li JR and Li ZB. Circulating levels of vascular endothelial growth factor in patients with oral squamous cell carcinoma. International journal of oral and maxillofacial surgery. 2002; 31(5):495-498.

89. Kyzas PA, Stefanou D, Batistatou A and Agnantis NJ. Hypoxia-induced tumor angiogenic pathway in head and neck cancer: an in vivo study. Cancer letters. 2005; 225(2):297-304.

90. Mohamed KM, Le, A., Duong, H., Wu, Y., Zhang, Q., Messadi, D.V. Correlation between VEGF and HIF-1alpha expression in human oral squamous cell carcinoma. Exp Mol Pathol. 2004; 76(2):143--152.

91. Shang ZJ, Li, Z.B., Li, J.R. VEGF is up-regulated by hypoxic stimulation and related to tumour angiogenesis and severity of disease in oral squamous cell carcinoma: in vitro and in vivo studies. Int J Maxillofac Surg. 2006; 35(6):533-538 .

92. Shemirani B. aC, D.L. Hypoxic induction of HIF-1alpha and VEGF expression in head and neck squamous cell carcinoma lines is mediated by stress activated protein kinases. Oral Oncol. 2002; 38(3):251--257.

93. Duffy AM, Bouchier-Hayes DJ and Harmey JH. (2000). Vascular Endothelial Growth Factor (VEGF) and its role in non-endothelial cells: Autocrine signalling by VEGF. In: Harmey JH, ed. VEGF and Cancer, pp. 133-144.

94. Kennedy A and Frank RN. The influence of glucose concentration and hypoxia on VEGF secretion by cultured retinal cells. Current eye research. 2011; 36(2):168-177.

95. Katavetin P, Miyata $T$, Inagi R, Tanaka $T$, Sassa R, Ingelfinger JR, Fujita T and Nangaku M. High glucose blunts vascular endothelial growth factor response to hypoxia via the oxidative stress-regulated hypoxia-inducible factor/hypoxia-responsible element pathway. Journal of the American Society of Nephrology. 2006; 17(5):1405-1413.

96. Shang ZJ and Li JR. Expression of endothelial nitric oxide synthase and vascular endothelial growth factor in oral squamous cell carcinoma: its correlation with angiogenesis and disease progression. J Oral Pathol Med. 2005; 34(3):134-139.

97. Shi XY, Hu, G.Q., Yuan, X.L., Li, H.Y., Ma, D. [Relationship between VEGF-C expression and nasopharyngeal carcinoma proliferation and metastasis]. [Article in Chinese]. Zhonghua Zhong Liu Za Zhi. 2006; 28(5):364-367.

98. Koppenol WH, Bounds PL and Dang CV. Otto Warburg >S contributions to current concepts of cancer metabolism. Nat Rev Cancer. 2011; 11(5):325-337.

99. Warburg O. [On the facultative anaerobiosis of cancer cells and its use in chemotherapy]. [Article in German]. Munch Med Wochenschr. 1961; 103:2504-2506.

100. Robey IF, Lien, A. D., Welsh, S. J., Baggett, B. K., and 
Gillies, R. J. Hypoxia-inducible factor-1a and the glycolytic phenotype in tumors. Neoplasia. 2005; 7(4):324--330.

101. Grimm M, Munz, A., Teriete, P., Nadtotschi, T., Reinert, S. GLUT-1(+)/TKTL1(+) coexpression predicts poor outcome in oral squamous cell carcinoma. Oral Surg Oral Med Oral Pathol Oral Radiol. 2014; 117(6):743--753.

102. Li S, Yang, X., Wang, P., Ran, X. The effects of GLUT1 on the survival of head and neck squamous cell carcinoma. Cell Physiol Biochem. 2013; 32(3):624--634.

103. Mayer A, Von Wallbrunn A and Vaupel P. Glucose metabolism of malignant cells is not regulated by transketolase-like (TKTL)-1. International Journal of Oncology. 2010; 37(2).

104. Walenta S, Wetterling M, Lehrke M, Schwickert G, Sundfor K, Rofstad EK and Mueller-Klieser W. High lactate levels predict likelihood of metastases, tumor recurrence, and restricted patient survival in human cervical cancers. Cancer Res. 2000; 60(4):916-921.

105. Peppicelli S, Bianchini, F., Calorini, L. Extracellular acidity, a «reappreciated» trait of tumor environment driving malignancy: perspectives in diagnosis and therapy. Cancer metastasis reviews. 2014; 33(2-3):823--832.

106. Brizel DM, Schroeder T, Scher RL, Walenta S, Clough RW, Dewhirst MW and Mueller-Klieser W. Elevated tumor lactate concentrations predict for an increased risk of metastases in head-and-neck cancer. International journal of radiation oncology, biology, physics. 2001; 51(2):349-353.

107. Ziebart T, Walenta S, Kunkel M, Reichert TE, Wagner $\mathrm{W}$ and Mueller-Klieser W. Metabolic and proteomic differentials in head and neck squamous cell carcinomas and normal gingival tissue. Journal of cancer research and clinical oncology. 2011; 137(2):193-199.

108. Mariappan R, Venkatraghavan L, Vertanian A, Agnihotri $\mathrm{S}$, Cynthia S, Reyhani S, Tung T, Khan $\mathrm{OH}$ and Zadeh G. Serum lactate as a potential biomarker of malignancy in primary adult brain tumours. Journal of clinical neuroscience. 2015; 22(1):144-148.

109. Metz L, Sirvent, P., Py, G., Brun, J.F., Fedou, C., Raynaud, E., Mercier, J. Relationship between blood lactate concentration and substrate utilization during exercise in type 2 diabetic postmenopausal women. Metabolism. 2005; 54(8):1102--1107.

110. Maturu P, and Varadacharyulu, N. Adaptive changes in fatty acid profile of erythrocyte membrane in relation to plasma and red cell metabolic changes in chronic alcoholic men. Hum Exp Toxicol. 2012; 31(7):652--661.

111. Walenta S, Salameh A, Lyng H, Evensen JF, Mitze M, Rofstad EK and Mueller-Klieser W. Correlation of high lactate levels in head and neck tumors with incidence of metastasis. Am J Pathol. 1997; 150(2):409-415.

112. Jensen DH, Therkildsen MH and Dabelsteen E. A reverse Warburg metabolism in oral squamous cell carcinoma is not dependent upon myofibroblasts. J Oral Pathol Med. 2015; 44(9):714-721.
113. Krupar R, Robold, K., Gaag, D., Spanier, G., Kreutz, M., Renner, K., Hellerbrand, C., Hofstaedter, F., Bosserhoff, A.K. Immunologic and metabolic characteristics of HPVnegative and HPV-positive head and neck squamous cell carcinomas are strikingly different. Virchows Arch. 2014; 465(3):299--312.

114. Walenta S, Schroeder, T., Mueller-Klieser, W. Lactate in solid malignant tumors: potential basis of a metabolic classification in clinical oncology. Curr Med Chem. 2004; 11(16):2195--2204.

115. Koukourakis MI, Giatromanolaki A, Winter S, Leek R, Sivridis E and Harris AL. Lactate dehydrogenase 5 expression in squamous cell head and neck cancer relates to prognosis following radical or postoperative radiotherapy. Oncology. 2009; 77(5):285-292.

116. Hsieh YY, Mu-Hsin Chang P, Chen MH, Chu PY, Tzeng $\mathrm{CH}$, Chang SY, Chen PM and Yang MH. Pretreatment risk stratification for non-metastatic head and neck squamous cell carcinoma in a high-prevalence area. Journal of the Chinese Medical Association. 2011; 74(11):487-492.

117. Yao Y, Wang $\mathrm{H}$ and $\mathrm{Li}$ B. LDH5 overexpression is associated with poor survival in patients with solid tumors: a meta-analysis. Tumour biology. 2014; 35(7):6973-6981.

118. De La Pena VA, Diz Dios P and Tojo Sierra R. Relationship between lactate dehydrogenase activity in saliva and oral health status. Archives of oral biology. 2007; 52(10):911915.

119. Shpitzer T, Bahar G, Feinmesser R and Nagler RM. A comprehensive salivary analysis for oral cancer diagnosis. Journal of cancer research and clinical oncology. 2007; 133(9):613-617.

120. Sattler UG, Meyer SS, Quennet V, Hoerner C, Knoerzer H, Fabian C, Yaromina A, Zips D, Walenta S, Baumann $\mathrm{M}$ and Mueller-Klieser W. Glycolytic metabolism and tumour response to fractionated irradiation. Radiotherapy and oncology. 2010; 94(1):102-109.

121. Ross CD, Gomaa MA, Gillies E, Juengel R and Medina JE. Tumor grade, microvessel density, and activities of malate dehydrogenase, lactate dehydrogenase, and hexokinase in squamous cell carcinoma. Otolaryngology--head and neck surgery. 2000; 122(2):195-200.

122. Erez A, Shental O, Tchebiner JZ, Laufer-Perl M, Wasserman A, Sella T and Guzner-Gur H. Diagnostic and Prognostic Value of Very High Serum Lactate Dehydrogenase in Admitted Medical Patients. Isr Med Assoc J. 2014; 16(7):439-443.

123. Goethals L, Debucquoy, A., Perneel, C., Geboes, K., Ectors, N., De Schutter, H., Pennincky, F., McBride, W.H., Begg, A.C., Haustermans, K.M. Hypoxia in human colorectal adenocarcinoma: comparison between extrinsic and potential intrinsic hypoxia markers. Int $\mathrm{J}$ Radiation Oncology Biol Phys. 2006; 65(1):246--254.

124. Mayer A, Hockel M, Wree A and Vaupel P. Microregional expression of glucose transporter-1 and oxygenation status: 
lack of correlation in locally advanced cervical cancers. Clinical cancer research. 2005; 11(7):2768-2773.

125. Beasley NJ, Wykoff, C. C., Watson, P. H., Leek, R., Turley, H., Gatter, K., Pastorek, J., Cox, G. J., Ratcliffe, P., and Harris, A. L. Carbonic anhydrase IX, an endogenous hypoxia marker, expression in head and neck squamous cell carcinoma and its relationship to hypoxia, necrosis and microvessel density. Cancer Res. 2001; 61(13):5262--5267.

126. Peridis S, Pilgrim, G., Athanasopoulos, I., Parpounas, K. Carbonic anhydrase-9 expression in head and neck cancer: a meta-analysis. European archives of oto-rhino-laryngology. 2011; 268(5):661--670.

127. Brockton N, Dort J, Lau H, Hao D, Brar S, Klimowicz A, Petrillo S, Diaz R, Doll C and Magliocco A. High stromal carbonic anhydrase IX expression is associated with decreased survival in P16-negative head-and-neck tumors. International journal of radiation oncology, biology, physics. 2011; 80(1):249-257.

128. Brockton NT, Klimowicz AC, Bose P, Petrillo SK, Konno M, Rudmik L, Dean M, Nakoneshny SC, Matthews TW, Chandarana S, Lau HY, Magliocco AM and Dort JC. High stromal carbonic anhydrase IX expression is associated with nodal metastasis and decreased survival in patients with surgically-treated oral cavity squamous cell carcinoma. Oral oncology. 2012; 48(7):615-622.

129. Courter D, Cao HB, Kwok S, Kong C, Banh A, Kuo PW, Bouley DM, Vice C, Brustugun OT, Denko NC, Koong AC, Giaccia A and Le QT. The RGD Domain of Human Osteopontin Promotes Tumor Growth and Metastasis through Activation of Survival Pathways. PloS one. 2010; 5(3):e9633.

130. Le QT and Courter D. Clinical biomarkers for hypoxia targeting. Cancer metastasis reviews. 2008; 27(3):351-362.

131. Bache M, Reddemann R, Said HM, Holzhausen HJ, Taubert H, Becker A, Kuhnt T, Hansgen G, Dunst J and Vordermark D. Immunohistochemical detection of osteopontin in advanced head-and-neck cancer: prognostic role and correlation with oxygen electrode measurements, hypoxiainducible-factor-1alpha-related markers, and hemoglobin levels. International journal of radiation oncology, biology, physics. 2006; 66(5):1481-1487.

132. Overgaard J, Eriksen JG, Nordsmark M, Alsner J, Horsman MR, Danish H and Neck Cancer Study G. Plasma osteopontin, hypoxia, and response to the hypoxia sensitiser nimorazole in radiotherapy of head and neck cancer: results from the DAHANCA 5 randomised double-blind placebocontrolled trial. Lancet Oncol. 2005; 6(10):757-764.

133. Lim AM, Rischin D, Fisher R, Cao H, Kwok K, Truong D, McArthur GA, Young RJ, Giaccia A, Peters L and Le QT. Prognostic significance of plasma osteopontin in patients with locoregionally advanced head and neck squamous cell carcinoma treated on TROG 02.02 phase III trial. Clinical cancer research. 2012; 18(1):301-307.

134. Hui EP, Sung FL, Yu BK, Wong CS, Ma BB, Lin X, Chan A, Wong WL and Chan AT. Plasma osteopontin, hypoxia, and response to radiotherapy in nasopharyngeal cancer. Clinical cancer research. 2008; 14(21):7080-7087.

135. Ahmad R, Al-Mass A, Al-Ghawas D, Shareif N, Zghoul N, Melhem M, Hasan A, Al-Ghimlas F, Dermime S and Behbehani K. Interaction of osteopontin with IL-18 in obese individuals: implications for insulin resistance. PloS one. 2013; 8(5):e63944.

136. Bellovici M, Ketelslegers JM, Colson A, de Coninck V and Buysschaert M. Smoking is associated with increased levels of osteopontin in type 2 diabetic patients: preliminary results. Diabetes \& Metabolism. 2006; 32(5):485-486.

137. Ohashi M, Iwase M and Nagumo M. Elevated production of salivary nitric oxide in oral mucosal diseases. J Oral Pathol Med. 1999; 28(8):355-359.

138. Beevi SS, Rasheed AM and Geetha A. Evaluation of oxidative stress and nitric oxide levels in patients with oral cavity cancer. Jpn J Clin Oncol. 2004; 34(7):379-385.

139. Gokul S, Patil VS, Jailkhani R, Hallikeri K and Kattappagari KK. Oxidant-antioxidant status in blood and tumor tissue of oral squamous cell carcinoma patients. Oral diseases. 2010; 16(1):29-33.

140. Korde SD, Basak A, Chaudhary M, Goyal M and Vagga A. Enhanced nitrosative and oxidative stress with decreased total antioxidant capacity in patients with oral precancer and oral squamous cell carcinoma. Oncology. 2011; 80(56):382-389.

141. Wenger RH. Cellular adaptation to hypoxia: O2-sensing protein hydroxylases, hypoxia-inducible transcription factors, and O2-regulated gene expression. FASEB J. 2002; 16(10):1151--1162.

142. Zhao SF, Tong XY and Zhu FD. Nitric oxide induces oral squamous cell carcinoma cells apoptosis with p53 accumulation. Oral oncology. 2005; 41(8):785-790.

143. Adduri RSR, Kotapalli V, Gupta NA, Gowrishankar S, Srinivasulu M, Ali MM, Rao S, Uppin SG, Nayak UK, Dhagam S, Chigurupati MV and Bashyam MD. P53 nuclear stabilization is associated with FHIT loss and younger age of onset in squamous cell carcinoma of oral tongue. BMC Clinical Pathology. 2014; 14:37.

144. Kimple RJ, Smith, M.A., Blitzer, G.C., Torres, A.D., Martin, J.A., Yang, R.Z., Peet, C.R., Lorenz, L.D., Nickel, K.P., Klingelhutz, A.J., Lambert, P.F., Harari, P.M. Enhanced radiation sensitivity in HPV-positive head and neck cancer. Cancer Res. 2013; 73(15):4791--4800.

145. Portugal LG, Goldenberg JD, Wenig BL, Ferrer KT, Nodzenski E, Sabnani JB, Javier C, Weichselbaum RR and Vokes EE. Human papillomavirus expression and p53 gene mutations in squamous cell carcinoma. Arch Otolaryngol Head Neck Surg. 1997; 123(11):1230-1234.

146. Sorensen DM, Lewark, T.M., Haney, J.L., Meyers, A.D., Krause, G., Franklin, W.A. Absence of p53 mutations in squamous carcinomas of the tongue in nonsmoking and nondrinking patients younger than 40 years. Arch, Otolaryngol Head Neck Surg. 1997; 123(5):503--506. 
147. Robertson ED, Semenchenko, K., Wasylyk, B. Crosstalk between Mdm2, p53, HIF1-alpha: Distinct responses to oxygen stress and implications for tumour hypoxia. Subcell Biochem. 2014; 85:199--214.

148. Hedback N, Jensen DH, Specht L, Fiehn AM, Therkildsen MH, Friis-Hansen L, Dabelsteen E and von Buchwald C. MiR-21 expression in the tumor stroma of oral squamous cell carcinoma: an independent biomarker of disease free survival. PloS one. 2014; 9(4):e95193.

149. Chen D, Cabay RJ, Jin Y, Wang A, Lu Y, Shah-Khan M and Zhou X. MicroRNA Deregulations in Head and Neck Squamous Cell Carcinomas. Journal of oral \& maxillofacial research. 2013; 4(1):e2.

150. Fu X, Han, Y., Wu, Y., Zhu, X., Lu, X., Mao, F., Wang, X., He, X., Zhao, Y., and Zhao, Y. Prognostic role of microRNA-21 in various carcinomas: a systematic review and meta-analysis. Eur J Clin Invest. 2011; 41(11):1245-1253.

151. Polytarchou C, Iliopoulos, D., Hatziapostolou, M., Kottakis, F., Maroulakou, I, Struhl, K., and Tsichlis, P. N. Akt2 regulates all Akt isoforms and promotes resistance to hypoxia through induction of miR-21 upon oxygen deprivation. Cancer Rs. 2011; 71(13):4720--4731.

152. Loayza-Puch F, Yoshida, Y., Matsuzaki, T., Takahashi, C., Kitayama, H., and Noda, M. Hypoxia and RAS-signaling pathways converge on, and cooperatively downregulate, the RECK tumor-suppressor protein through microRNAs. Oncogene. 2010; 29:2638--2648.

153. Ivan M, and Huang, X. miR-210: fine-tuning the hypoxic response. Adv Exp Med Biol. 2014; 772:205--227.

154. Janiszewska J, Szaumkessel, M., and Szyfter, K. microRNAs are important players in head and neck carcinoma: A review. Critical Review in Oncology/ Hematology. 2013; 88:716--728.

155. Toustrup K, Sorensen BS, Alsner J and Overgaard J. Hypoxia gene expression signatures as prognostic and predictive markers in head and neck radiotherapy. Semin Radiat Oncol. 2012; 22(2):119-127.

156. Toustrup K, Sorensen BS, Nordsmark M, Busk M, Wiuf C, Alsner J and Overgaard J. Development of a hypoxia gene expression classifier with predictive impact for hypoxic modification of radiotherapy in head and neck cancer. Cancer Res. 2011; 71(17):5923-5931.

157. Higuchi C, Nakatsuka, A., Eguchi, J., Teshigawara, S., Kanzaki, M., Katayama, A., Yamaguchi, S., Takahashi, N., Murakami, K., Ogawa, S., Sasaki, S., Makino, H., and Wada, J. Identification of circulating miR-101, miR-375 and miR-802 as biomarkers for type 2 diabetes. Metabolism. 2015; 64(4):489--497.

158. Luo J, Wu J, Li Z, Qin H, Wang B, Wong TS, Yang W, Fu QL and Lei W. miR-375 suppresses IGF1R expression and contributes to inhibition of cell progression in laryngeal squamous cell carcinoma. Biomed Res Int. 2014; 2014:374598.
159. Bar J, Spencer S, Morgan S, Brooks L, Cunningham D, Robertson J, Jurgensmeier JM and Goss GD. Correlation of lactate dehydrogenase isoenzyme profile with outcome in patients with advanced colorectal cancer treated with chemotherapy and bevacizumab or cediranib: Retrospective analysis of the HORIZON I study. Clinical colorectal cancer. 2014; 13(1):46-53.

160. Siow MY, Ng, L. P., Vincent-Chong, V. K., Jamaludin, M., Abraham, M. T., Abdul Rahman, Z. A., Kallarakkal, T. G., Yang, Y. H., Cheong, S. C., and Zain, R. B. Dysregulation of miR-31 and miR-375 expression is associated with clinical outcome in oral carcinoma. Oral diseases. 2014; 20(4):245--251.

161. Eustace A, Mani N, Span PN, Irlam JJ, Taylor J, Betts GN, Denley H, Miller CJ, Homer JJ, Rojas AM, Hoskin PJ, Buffa FM, Harris AL, Kaanders JH and West CM. A 26-gene hypoxia signature predicts benefit from hypoxiamodifying therapy in laryngeal cancer but not bladder cancer. Clinical cancer research. 2013; 19(17):4879-4888.

162. Buffa FM, Harris AL, West CM and Miller CJ. Large metaanalysis of multiple cancers reveals a common, compact and highly prognostic hypoxia metagene. British journal of cancer. 2010; 102(2):428-435.

163. Winter SC, Buffa FM, Silva P, Miller C, Valentine HR, Turley H, Shah KA, Cox GJ, Corbridge RJ, Homer JJ, Musgrove B, Slevin N, Sloan P, Price P, West CM and Harris AL. Relation of a hypoxia metagene derived from head and neck cancer to prognosis of multiple cancers. Cancer Res. 2007; 67(7):3441-3449.

164. Zimny M, Gagel B, DiMartino E, Hamacher K, Coenen $\mathrm{HH}$, Westhofen M, Eble M, Buell U and Reinartz P. FDG-a marker of tumour hypoxia? A comparison with [18F] fluoromisonidazole and pO2-polarography in metastatic head and neck cancer. Eur J Nucl Med Mol Imaging. 2006; 33(12):1426-1431.

165. Gaddikeri S, Gaddikeri RS, Tailor T and Anzai Y. Dynamic Contrast-Enhanced MR Imaging in Head and Neck Cancer: Techniques and Clinical Applications. AJNR Am J Neuroradiol. 2016; 37(4):588-595.

166. Koyasu S, Tsuji Y, Harada H, Nakamoto Y, Nobashi T, Kimura H, Sano K, Koizumi K, Hamaji M and Togashi K. Evaluation of Tumor-associated Stroma and Its Relationship with Tumor Hypoxia Using Dynamic Contrast-enhanced CT and (18)F Misonidazole PET in Murine Tumor Models. Radiology. 2016; 278(3):734-741.

167. Wiedenmann NE, Bucher S, Hentschel M, Mix M, Vach W, Bittner MI, Nestle U, Pfeiffer J, Weber WA and Grosu AL. Serial [18F]-fluoromisonidazole PET during radiochemotherapy for locally advanced head and neck cancer and its correlation with outcome. Radiotherapy and oncology. 2015; 117(1):113-117.

168. Bruine de Bruin L, Bollineni VR, Wachters JE, Schuuring E, van Hemel BM, van der Wal JE, Slagter-Menkema L, de Bock GH, Steenbakkers RJ, Langendijk JA, Pruim J, van der Laan BF and Halmos GB. Assessment 
of hypoxic subvolumes in laryngeal cancer with (18) F-fluoroazomycinarabinoside ((18)F-FAZA)-PET/CT scanning and immunohistochemistry. Radiotherapy and oncology. 2015; 117(1):106-112.

169. Medical devices; classification of temporomandibular joint implants--FDA. Final rule. Fed Regist. 1994; 59(243):65475-65478.

170. Wachters JE, Schrijvers, M.L., Slagter-Menkema, L., Mastik, M., de Bock, G.H., Langendijk, J.A., Kluin, P.M., Schuuring, E., van der Laan, B.F., van der Wal, J.E. Prognostic significance of HIF-1a, CA-IX, and OPN in T1-T2 laryngeal carcinoma treated with radiotherapy. Laryngoscope. 2013; 123(9):2154--2160.

171. Schrijvers ML, van der Laan BF, de Bock GH, Pattje WJ, Mastik MF, Menkema L, Langendijk JA, Kluin PM, Schuuring E and van der Wal JE. Overexpression of intrinsic hypoxia markers HIF1alpha and CA-IX predict for local recurrence in stage T1-T2 glottic laryngeal carcinoma treated with radiotherapy. International journal of radiation oncology, biology, physics. 2008; 72(1):161-169.

172. Gong L, Zhang W, Zhou J, Lu J, Xiong H, Shi X and Chen J. Prognostic value of HIFs expression in head and neck cancer: a systematic review. PloS one. 2013; 8(9):e75094.

173. Rajendran R, Liang J, Tang MY, Henry B and Chuang KH. Optimization of arterial spin labeling MRI for quantitative tumor perfusion in a mouse xenograft model. NMR Biomed. 2015; 28(8):988-997.

174. Zhang ZW, Yuan Q, Zhou HL, Zhao DW, Li L, Gerberich $\mathrm{JL}$ and Mason RP. Assessment of tumor response to oxygen challenge using quantitative diffusion MRI in an animal model. Journal of Magnetic Resonance Imaging. 2015; 42(5):1450-+.

175. Goncalves MR, Johnson SP, Ramasawmy R, Pedley RB, Lythgoe MF and Walker-Samuel S. Decomposition of spontaneous fluctuations in tumour oxygenation using BOLD MRI and independent component analysis. British journal of cancer. 2015; 113(8):1168-1177.

176. Ang KK, Harris J, Wheeler R, Weber R, Rosenthal DI, Nguyen-Tan PF, Westra WH, Chung CH, Jordan RC, Lu C, Kim H, Axelrod R, Silverman CC, Redmond KP and Gillison ML. Human papillomavirus and survival of patients with oropharyngeal cancer. N Engl J Med. 2010; 363(1):24-35.

177. Sorensen BS, Busk M, Olthof N, Speel EJ, Horsman MR, Alsner $\mathrm{J}$ and Overgaard J. Radiosensitivity and effect of hypoxia in HPV positive head and neck cancer cells. Radiotherapy and oncology. 2013; 108(3):500-505.

178. Lajer CB, Nielsen, F. C., Friis-Hansen, L., Norrild, B., Borup, R., Garnaes, E., Rossing, M., Specht, L., Therkildsen, M. H., Nauntofte, B., Dabelsteen, S., and von Buchwald, C. Different miRNA signatures of oral and pharyngeal squamouse cell carcinomas: a prospective translational study. British journal of cancer. 2011; 104:830--840.
179. Nordfors C, Grün, N., Tertipis, N., àhrlund-Richter, A., Haeggblom, L., Sivars, L., Du, J., Nyberg, T., Marklund, L., Munch-Wikland, E., Näsman, A., Ramqvist, T., and Dalianis, T. CD8+ and CD4+ tumour infiltrating lymphocytes in relation to human papillomavirus status and clinical outcome in tonsillar and base of tongue squamous cell carcinoma. Eur J Cancer. 2013; 49(11):2522--2530.

180. Näsman A, Nordfors, C., Grün, N., Munch-Wikland, E., Ramqvist, T., Marklund, L., Lindquist, D., and Dalianis, T., . Absent/weak CD44 intensity and positive human papillomavirus (HPV) status in oropharyngeal squamous cell carcinoma indicates a very high survival. Cancer Med. 2013; 2(4):507--518.

181. Ye J, Liu, H., Hu, Y., Li, P., Zhang, G., and Li, Y. Tumoral indoleamine 2,3-dioxygenase expression predicts poor outcome in laryngeal squamous cell carcinoma. Virchows Arch. 2013; 462(1):73--81.

182. Badoual C, Hans, S., Merillon, N., Van Ryswick, C., Ravel, P., Benhamouda, N., Levionnois, E., Nizard, M., SiMohamed, A., Besnier, N., Gey, A., Rotem-Yehudar, R., Pere, H., Tran, T., Guerin, C. L., Chauvat, A., Dransart, E., Alanio, C., Albert, S., Barry, B., Sandoval, F., QuintinColonna, F., Bruneval, P., Fridman, W. H., Lemoine, F. M., Oudard, S., Johannes, L., Olive, D., Brasnu, D., and Tartour, E. PD-1-expressing tumor-infiltrating T cells are a favorable prognostic biomarker in HPV-associated head and neck cancer. Cancer Res. 2013; 73(1):128--138.

183. Li J, Mo, H. Y., Xiong, G., Zhang, L., He, J., Huang, Z. F., Liu, Z. W., Chen, Q. Y., Du, Z. M., Zheng, L. M., Qian, C. N., and Zeng, Y. X. Tumor microenvironment macrophage inhibitory factor directs the accumulation of interleukin17-producing tumor-infiltrating lymphocytes and predicts favorable survival in nasopharyngeal carcinoma patients. J Biol Chem. 2012; 287(42):35484--35495.

184. Fridman WH, Galon, J., Dieu-Nosjean, M. C., Cremer, I., Fisson, S., Damotte, D., Pages, F., Tartour, E., and Sautes-Fridman, C. Immune infiltration in human cancer: prognostic significance and disease control. Curr Top Microbiol Immunol. 2011; 344:1--24.

185. Elahi M, Rakhshan, V., Ghasemian, N. T., and Moshref, M. Prognostic value of transforming growth factor beta 1 (TGF-Beta1) and matrix metalloproteinase 9 (MMP-9) in oral squamous cell carcinoma. Biomarkers. 2012; 17(1):21-27 .

186. Osawa H, Nakajima, M., Kato, H., Fukuchi, M., and Kuwano, H. Prognostic value of the expression of Smad6 and Smad7, as inhibitory Smads of hte TGF-beta superfamily, in esophageal squamous cell carcinoma. Anticancer Res. 2004; 24(6):3703--3709.

187. Yang S, Chen, J., Guo, Y., Lin, H., Zhang, Z., Feng, G., Hao, Y., Cheng, J., Liang, P., Chen, K., Wu, H., and Li, $\mathrm{Y}$. Identification of prognostic biomarkers for response to radiotherapy by DNA microarray in nasopharyngeal carcinoma patients. Int J Oncol. 2012; 40(5):1590--1600.

188. Ohyama Y, Kawamoto, Y., Chiba, T., Maeda, G., Sakashita, 
H., and Imai, K. Inhibition of TGF-beta and EGF pathway gene expression and migration of oral carcinoma cells by mucosa-associated lymphoid tissue 1. Br J Cancer. 2013; 109(1):207--214.

189. Albert S, Hourseaue, M., Halimi, C., Serova, M., Descatoire, V., Barry, B., Couvelard, A., Riveiro, M. E., Tijeras-Raballand, A., de Gramont, A., Raymond, E., and Faivre, S. Prognostic value of the chemokine receptor CXCR4 and epithelial-to-mesenchymal transition in patients with squamous cell carcinoma of the mobile tongue. Oral Oncol. 2012; 48(12):1263--1271.

190. Bron L, Jandus, C., Andrejevic-Blant, S., Speiser, D. E., Monnier, P., Romero, P., and Rivals, J. P. Prognostic value of arginase-II expression and regulatory T-cell infiltration in head and neck squamous cell carcinoma. International journal of cancer. 2013; 132(3):E85--93.

191. Snietura M, Jaworska M, Mlynarczyk-Liszka J, GorajZajac A, Piglowski W, Lange D, Wozniak G, Nowara E and Suwinski R. PTEN as a Prognostic and Predictive Marker in Postoperative Radiotherapy for Squamous Cell Cancer of the Head and Neck. PloS one. 2012; 7(3):e33396.

192. Dionysopoulos D, Pavlakis, K., Kotoula, V., Fountzilas, E., Markou, K., Karasmanis, I., Angouridakis, N., Nikolaou, A., Kalogeras, K. T., and Fountzilas, G. Cyclin D1, EGFR and Akt/mTOR pathway. Potential prognostic markers in localized laryngeal squamous cell carcinoma. Strahlenther Onkol. 2013; 189(3):202--214.

193. Desai S, Ding, M., Wang, B., Lu, Z., Zhao, Q., Shaw, K., Yung, W. K., Weinstein, J. N., Tan, M. and Yao, J. Tissuespecific isoform switch and DNA hypomethylation of the pyruvat kinase PKM gene in human cancers. Oncotarget. 2014; 5(18):8202--8210. doi: 10.18632/oncotarget.1159.

194. Li F, Liu, Y., Kan, X., Li, Y., Liu, M., and Lu, J. G. Elevated expression of integrin av and beta5 subunit in laryngeal squamous cell carcinoma associated with lymphatic metastasis nad angiogenesis. Pathol Res Pract. 2013; 209(2):105--109.

195. McFate T, Mohyeldin, A., Lu, H., Thakar, J., Henriques, J., Halim, N. D., Wu, H., Schell, M. J., Tsang, T. M., Teahan, O., Zhou, S., Califano, J. A., Jeoung, N. H., Harris, R. A., and Verma, A. Pyruvate dehydrogenase complex activity controls metabolic and malignant phenotype in cancer cells. J Biol Chem. 2008; 283(33):22700--22708.

196. Klimowicz AC, Bose, P., Nakoneshny, S. C., Dean, M., Huang, L., Chandarana, S., Magliocco, A. M., Wayne Matthews, T., Brockton, N., T., and Dort, J. C. Basal Ki67 expression measured by digital image analysis is optimal for prognostication in oral squamous cell carcinoma. Eur $\mathrm{J}$ Cancer. 2012; 48(14):2166--2174.

197. Moreno-Galindo C, Hermsen, M., Garcia-Pedrero, J. M., Fresno, M. F., Suarez, C., and Rodrigo, J. P. p27 and BCL2 expression predicts response to chemotherapy in head and neck squamous cell carcinomas. Oral Oncol. 2014; 50(2):128--134.

198. Bentzen SM, Atasoy, B. M., Daley, F. M., Dische, S.,
Richman, P. I., Saunders, M. I., Trott, K. R., and Wilson, G. D. Epidermal growth factor receptor expression in pretreatment biopsies from head and neck squamous cell carcinoma as a predictive factor for a benefit from accelerated radiation therapy in a randomized controlled trial. J Clin Oncol. 2005; 23(24):5560--5567.

199. Albinger-Hegyi A, Stoeckli, S. J., Schmid, S., Storz, M., Iotzova, G., Probst-Hensch, N. M., Rehrauer, H., Tinguely, M., Moch, H. and Hegyi, I. Lysyl oxidase expression is an independent marker of prognosis and a predictor of lymph node metastasis in oral and oropharyngeal squamous cell carcinoma (OSCC). International journal of cancer. 2010; 126(11):2653--2662.

200. Ogbureke KU, Weinberger, P. M., Looney, S. W., Li, L., and Fisher, L. W. Expressions of matrix metalloproteinase-9 (MMP-9), dentin sialophosphoprotein (DSPP) and osteopontin (OPN) at histologically negative surgical margins may predict recurrence of oral squamous cell carcinoma. Oncotarget. 2012; 3(3):286--298. doi: 10.18632/ oncotarget.373.

201. Mäkinen LK, Häyry, V., Atula, T., Haglund, C., KeskiSäntti, H., Leivo, I., Mäkitie, A., Passador-Santos, F., Böckelman, C., Salo, T., Sorsa, T., and Hagström, J. Prognostic significance of matrix metalloproteinase-2, -8, -9 , and -13 in oral tongue cancer. J Oral Pathol Med. 2012; 41(5):394--399.

202. Zheng M, Li, L., Tang, Y. L., and Liang, X. H. Biomarkers in tongue cancer: understanding the molecular basis and their clinical implications. Postgrad Med J. 2010; 86(1015):292--298.

203. Bleijerveld OB, Brakenhoff, R. H., Schaaij-Visser, T. B., Damen, J. M., Altelaar, A. F., Heck, A. J., and Siliper M. Protein signatures associated with tumor cell dissemination in head and neck cancer. J Proteomics. 2011; 74(4):558-566.

204. Zhang J, Cheng, Q., Zhou, Y., Wang, Y., and Chen, X. Slug is a key mediator of hypoxia induced cadherin switch in HNSCC: correlations with poor prognosis. Oral oncology. 2013; 49(11):1043--1050.

205. Chang HH, Chiang, C. P., Hung, H. C., Lin, C. Y., Deng, Y. T., and Kuo, M. Y. Histone deacetylase 2 expression predicts poorer prognosis in oral cancer patients. Oral oncology. 2009; 45(7):610--614.

206. Chang CC, Lin, B. R., Chen, S. T. Hsieh, T. H., Li, Y. J., and Kuo, M. Y. HDAC2 promotes cell migration/invasion abilities through HIF-1alpha stabilization in human oral squamous cell carcinoma. J Oral Pathol Med. 2011; 40(7):567--575.

207. Chang CC, Hsu, W. H., Wang, C. C., Chou, C. H., Kuo, M. Y., Lin, B. R., Chen, S. T., Tai, S. K., Kuo, M. L., and Yang, M., H. Connective tissue growth factor activates pluripotency genes and mesenchymal-epithelial transition in head and neck cancer cells. Cancer Res. 2013; 73(13):4147$-4157$.

208. Alves PM, Godoy, G. P., Gomes, D. Q., Medeiros, A. M., 
de Souza, L. B., da Silveira, E. J., Vasconcelos, M. G., and Queiroz, L. M. Significance of galectins-1, -3, -4 and -7 in the progression of squamous cell carcinoma of the tongue. Pathology, research and practice. 2011; 207(4):236--240. 